\title{
Arsène Lupin, Gentleman Cambrioleur adlı eserin Osmanlı Türkçesi (yeniden) çevirileri üzerine betimleyici bir çalışma ${ }^{1}$
}

Gülay GÜLER²

\section{Ayşe Banu KARADAĞ3}

\begin{abstract}
APA: Güler, G.; Karadağ, A. B. (2020). Arsène Lupin, Gentleman Cambrioleur adlı eserin Osmanlı Türkçesi (yeniden) çevirileri üzerine betimleyici bir çalışma. RumeliDE Dil ve Edebiyat Araştırmaları Dergisi, (Ö7), 654-682. DOI: 10.29000/rumelide.808792.
\end{abstract}

\section{$\ddot{O} \mathbf{z}$}

Türk kültür ve edebiyat dizgesine çeviri yoluyla giren polisiye türünün doğuşu ve gelişimi açısından çeviri etkinliğinin önemi yadsınamaz niteliktedir. Özellikle II. Meşrutiyet’in ilanından itibaren Batı dillerinden Osmanlı Türkçesine çok sayıda polisiye roman çevirisi yapıldığı söylenebilir. Nitekim polisiye edebiyat alanının önde gelen uzmanlarından Seval Şahin, "Auratik Hırsızın Tarihsel Sermayesi” adlı çalışmasında bu edebî türün, çok sayıda polisiye roman ve hikâyenin yayımlanmış olduğu II. Meşrutiyet Dönemi’nde altın çağını yaşadı̆̆ını vurgular (2011: 16). Maurice Leblanc tarafından kaleme alınan Arsène Lupin, polisiye romanlar arasında Türkçeye en çok çevrilen eserlerden biri olarak kabul edilmektedir. Bu makalenin amacı, Arsène Lupin, Gentleman Cambrioleur adlı eserin Osmanlı Türkçesi (yeniden) çevirileri üzerine betimleyici bir çalışma yapmaktır. Söz konusu eserin 1908-1928 yılları arasında yayımlanmış olan beş farklı çevirisi makalenin temel inceleme nesnesini oluşturmaktadır. Fazlı Necip (1325) [1909], Osman Vefik (1325) [1909], Süleyman Tevfik (1333) [1917], Mustafa Remzi (1341) [1925] ve Hasan Bedreddin'e (1926) ait olan bu çeviriler, çeviri tarihimize ışı tutabilmek amacıyla yan-metinsel ögeler bağlamında betimlenecektir. Bu amaç doğrultusunda, çeviri eserler ve bu eserlerde yan-metinsel ögeler olarak yer alan ön söz/son söz ve kitap kapakları hakkında genel bilgi verilecektir. Makalenin sonunda ise kaynak metnin ilk bölümünü oluşturan "L'arrestation d'Arsène Lupin”in Osmanlı Türkçesi çevirilerde nasıl öykülendiği üzerine karşılaştırmalı bir inceleme yapılacaktır.

Anahtar kelimeler: Polisiye roman çevirisi, Arsène Lupin, Gentleman Cambrioleur, yanmetinsel ögeler

\section{A descriptive study on the Ottoman Turkish (re)translations of Arsène Lupin, Gentleman Cambrioleur}

\begin{abstract}
The importance of translation activity is undeniable in terms of the birth and development of the crime fiction which has entered the Turkish cultural and literary system through translation. It is possible to say that many crime fiction translations from Western languages into Ottoman Turkish were carried out especially during the Second Constitutional Era. In her article entitled "Auratik

1 Bu makale, Öğr. Gör. Gülay GÜLER’in Prof. Dr. Ayş̧e Banu KARADAĞ’’n danışmanlığında hazırladığı “Türkçede Arsène Lupin Çevirileri Üzerine Betimleyici Bir Çalışma” başlıklı doktora tezinden üretilmiştir (Yıldız Teknik Üniversitesi, Sosyal Bilimler Enstitüsü, Diller ve Kültürlerarası Çeviribilim Doktora Programı).

2 Öğr. Gör., Sivas Cumhuriyet Üniversitesi, Yabancı Diller Yüksekokulu, Fransızca Bölümü (Sivas, Türkiye), gulaypartal@hotmail.com, ORCID ID: oooo-0003-1074-3011 [Makale kayıt tarihi: 21.08.2020-kabul tarihi: 20.10.2020; DOI: 10.29000/rumelide.808792]

3 Prof. Dr., Yıldız Teknik Üniversitesi, Edebiyat Fakültesi, Batı Dilleri ve Edebiyatları Bölümü, Mütercim Tercümanlı (Fransızca) ABD (İstanbul, Türkiye), akaradag@yildiz.edu.tr, ORCID ID: 000o-0002-0974-8053
\end{abstract}

Adres

Kırklareli Üniversitesi, Fen Edebiyat Fakültesi, Türk Dili ve Edebiyatı Bölümü, Kayalı Kampüsü-Kırklareli/TÜRKIYE e-posta: editor@rumelide.com 
Hırsızın Tarihsel Sermayesi”, Seval Şahin, one of the leading experts in the field of crime fiction, emphasizes that this literary genre lived its golden age in the Second Constitutional Era during which many crime novels and stories were published (2011: 16). Arsène Lupin, written by Maurice Leblanc, is considered as one of the most translated crime fiction works into Turkish. The aim of this article is to do a descriptive study on Arsène Lupin, Gentleman Cambrioleur's Ottoman Turkish (re)translations. Five different translations of the work which were published between 1908-1928 constitute the main object of the article. These translations belonging to Fazlı Necip (1325) [1909], Osman Vefik (1325) [1909], Süleyman Tevfik (1333) [1917], Mustafa Remzi (1341) [1925], and Hasan Bedreddin (1926) will be described in terms of paratextual elements in order to shed light on our

translation history. With this aim in view, general information will be given about the translated works and their prefaces, epilogues and book covers as paratextual elements. At the end of the article, a comparative analysis will be provided on how "L'arrestation d'Arsène Lupin", the first story of the book, is narrated in Ottoman Turkish translations.

Keywords: Crime fiction translation, Arsène Lupin, Gentleman Cambrioleur, paratextual elements.

\section{Giriş}

Fransız yazar Maurice Leblanc'ın kaleme aldığı Arsène Lupin serisinin hem çeviri hem de telif romanlara kaynaklık etme yoluyla Türk kültür ve edebiyat dizgesinde polisiye romanın oluşması ve gelişmesi açısından önemli bir yere sahip olduğu iddia edilebilir. Nitekim Batılı diğer polisiye kahramanlar gibi Arsène Lupin’in de yerli örneklerinin olduğu ifade edilmektedir:

Bu dönemde (II. Meşrutiyet) Sherlock Holmes, Nik Karter, Nat Pinkerton ve Arsen Lüpen'in Türk edebiyatındaki karşılıkları ortaya çıkar. Türklerin Sherlock Holmes’i Amanvermez Avni’nin yanı sıra bir de Türk Arsen Lüpen’i Nâhid Sâmi vardır. Bu ilk Türk Arsen Lüpen’ini Süleyman Sûdî ve E. Âli birlikte yazdıkları Gece Kuşları romanında ortaya çıkarırlar. 1914 yılında yayımlanan bu kitabın kapağında şöyle yazmaktadır: "İstanbul'u hayretler içinde bırakan memûrîn-i zâbıtaya uykusuz geceler geçirten Türk Arsen Lüpen’inin harikulâde sergüzeştlerini İstanbul kibar hayatının zevkâlûd köşelerini, Beyoğlu âleminin en esrarengiz noktalarını bütün vuzûhuyla tasvir eden hakiki millî romandır" (Şahin, 2009: 180).

Bu makalede, söz konusu seride yer alan ve incelenen dönemde en çok yeniden çevirisi yapılan Arsène Lupin, Gentleman Cambrioleur adlı eserin Osmanlı Türkçesindeki çevirileri irdelenecektir. Eserin, 1908-1928 yılları arasında farklı çevirmenler tarafından yapılmış beş çevirisi bulunmaktadır. Kısa bir zaman diliminde aynı eserin beş farklı çevirisinin yapılmış olması, Türk edebiyatında yeni bir tür olan polisiye romanın kendini Türk okuruna kabul ettirdiğinin bir işareti olarak yorumlanabilir.

Kitap kapakları ve tanıtım yazıları dâhil olmak üzere çevirilerin başında ve/veya sonunda yer alan metinlerin çeviri tarihi açısından önem taşıdığı belirtilmektedir. ${ }^{4} \mathrm{Bu}$ nedenle, çeviri tarihimize 1 şık tutmak adına söz konusu metinlerin çeviriyazısı yapılacak ve bu metinler diliçi çevirilerle günümüz Türkçesine aktarılacaktır.

4 Çeviribilim alanında ön söz/son söz odağındaki çalışmalara örnek olarak bkz. Tahir Gürçağlar, 2002; Akbulut, 2011; Bozkurt-Karadağ, 2012; Karadağ, 2014; Bozkurt, 2014; Karadă̆-Bozkurt, 2014.

Adres

Kırklareli Üniversitesi, Fen Edebiyat Fakültesi, Türk Dili ve Edebiyatı Bölümü, Kayalı Kampüsü-Kırklareli/TÜRKIYE e-posta: editor@rumelide.com
Address

Kırklareli University, Faculty of Arts and Sciences, Department of Turkish Language and Literature, Kayalı Campus-Kırklareli/TURKEY e-mail: editor@rumelide.com 
A descriptive study on the Ottoman Turkish (re)translations of Arsène Lupin, Gentleman Cambrioleur / G. Güler; A. B. Karadağ (pp. 654-682)

Belirtilen tarihlerdeki Arsène Lupin, Gentleman Cambrioleur çevirilerini tespit etmek için Seyfettin Özege'nin beş ciltten oluşan Eski Harflerle Basılmış Türkçe Eserler Kataloğu (1971, 1973, 1975, 1977, 1979) temel kaynak olarak alınmıştır.

Ülkemizde polisiye romanla ilgili gerek Türk dili ve edebiyatı gerekse çeviribilim alanında birçok çalışma yapılmış ve yapılmaktadır. Çalışmalar arasında, Erol Üyepazarcı'nın kaleme aldığı Korkmayını Mister Sherlock Holmes!. Türkiye’de Polisiye Romanın 125 Ylllk Öyküsü adlı eserin, polisiye romanın doğuşuna ve gelişimine dair kapsamlı bir bakış açısı sunması açısından büyük önem taşıdığı görülür. Bir diğer kapsamlı çalışma ise Türk edebiyatında polisiye romanın tarihsel gelişiminin ele alındı̆̆ , TÜBİTAK bünyesinde hazırlanan bir projedir. ${ }^{5}$ Söz konusu proje kapsamında 1884-1928 yılları arasında Osmanlı Türkçesinde yazılmış 232 polisiye romanın incelemesi yapılmış ve OsmanlıTürk polisiyesinin özellikleri belirlenmeye çalışılmıştır. Bunların yanı sıra ülkemizde polisiye roman ve çevirileri üzerine yapılmış birçok değerli çalışma bulunmaktadır. ${ }^{6}$

\section{Arsène Lupin, Gentleman Cambrioleur'ün yeniden çevirileri}

Daha önce çevrilmiş bir metnin aynı dilde eş zamanlı ya da art zamanlı olarak tekrar çevrilmesi anlamına gelen yeniden çeviri, uzun yıllardır çeviribilim alanında tartışılan, özellikle de 1990'lı ylllardan itibaren görünürlüğü artan bir kavramdır. Bu makalede amaç, daha önce de belirtildiği üzere Arsène Lupin (yeniden) çevirilerini betimlemektir. Bu doğrultuda "yeniden çeviri" kavramının literatüre kim tarafından, nasıl kazandırıldığı konusunda genel bir giriş yapılacak, kavramın ilerleyen dönemlerde ne şekilde ele alındığı hakkında ana hatlarıyla bilgi verilecektir. "Yeniden çeviri" üzerine yürütülecek bir kavramsal tartışmanın bu makalenin amacını ve kapsamını aştığı düşünüldüğünden böyle bir irdelemeye yer verilmeyecektir.

Tarihsel olarak bakıldığında, yeniden çeviri üzerine ilk önemli çalışmaların, Paul Bensimon (1990) ve Antoine Berman'ın (1990) Palimpsestes dergisinin yeniden çeviriye ayrılan özel sayısında yayımlanmış makaleleri olduğu görülür.7 Bensimon, çalışmasında ilk çevirilerin neden erek odaklı, sonraki çevirilerin ise neden kaynak odaklı olduğunu açıklamaya çalışır. İlk çevirilerin çoğunlukla yabancı eseri yerlileştirme eğiliminde olduğunu, erek kültürde daha kolay kabul görmesi için eserin yabancılığını azaltmaya çalıştığını savunur (Bensimon, 1990: ix) ${ }^{8}$. Bir eserin ilk çevirisinden sonra yapılan her çevirisini "yeniden çeviri" olarak tanımlayan Berman ise yeniden çeviriyi bir çeviriden diğer çeviriye doğru ilerleyen bir tamamlama süreci olarak değerlendirir. Berman'a göre çeviri tamamlanmamış bir eylemdir ve tamamlanma sadece yeniden çeviri yoluyla gerçekleşebilir (1990: 1).

Her yeniden çeviriyi kaynak metne doğru bir ilerleme olarak ele alan araştırmacılardan biri de Yves Gambier'dir. Gambier, yeniden çeviriyi daha önce çevrilmiş bir metnin tamamının ya da bir bölümünün aynı dilde tekrar çevrilmesi olarak tanımlar ve ilk çevirilerin okurun beğenisine, ihtiyacına, algısına göre yapıldığını iddia eder (1994: 413). Yeniden çevirinin "kaynak metne bir dönüşten ibaret" olduğunu ve ilk çevirilerdeki eksikliklerin ikinci çevirilerdeki kaynak metne yaklaşma çabalarıyla giderilebileceğini savunur (age. 414).

5 Seval Şahin, Didem Ardalı Büyükarman, Banu Öztürk, Ayşe Şahin, İpek Şahbenderoğlu, “1884-1928'de Türkiye’de Yayımlanmıș Telif Polisiye Eserlerin Tarihi”, TÜBİTAK Projesi, İstanbul, 2011-2014.

Polisiye roman ve çevirileri üzerine yapılan çalışmalara örnek olarak bkz. Altıntaş Balcı, 2005; Çelenk, 2005; Gezer, 2006; Türkeli, 2005; Gündüz, 2009; Şahin-Öztürk-Ardalı Büyükarman, 2013; Altıntaş-Karadă̆, 2019 a ve 2019b.

"Yeniden çeviri” odağında kuşkusuz birçok çalışma bulunmaktadır. Bunlarla sınırlı olmadığını vurgulayarak birkaç örnek vermek gerekirse bkz. Pym, 1998; Chesterman, 2000; Koskinen-Paloposki, 2003; Susam Sarajeva, 2003; Venuti, 2004; Brownlie, 2006; Koskinen-Paloposki, 2010; Paloposki-Koskinen, 2010; Birkan Baydan, 2015; Güneş, 2018; Berk Albachten-Tahir Gürçağlar, 2019a ve 2019b.

8 Aksi belirtilmedikçe çeviriler tarafımızca yapılmıştır. 
Yeniden çeviri alanındaki çalışmalara farklı bir bakış açısı getiren Kaisa Koskinen ve Outi Paloposki (2010) ise sonraki çevirilerin kaynak metne yakın olduğu iddiasının, yeniden çevirinin nedenlerini açıklamada yetersiz kaldığını ve yeniden çevirinin ardında yatan birçok etkenin bulunduğunu iddia eder. Kaynak metin odaklı yapılan çeviri değerlendirmelerini tek boyutlu olmakla eleştiren araştırmacılar, tam bir değerlendirmenin yapılabilmesi için yeniden çevirinin çok çeşitli olası nedenlerinin araştırılması gerektiğini vurgular (Paloposki ve Koskinen, 2004: 27-38). Yeniden çevirilerin, "aşamalı bir tamamlanma" meselesinden ziyade değişen ihtiyaçların ve algıların sonucu olarak ortaya çıktığını öne sürerler (Koskinen ve Paloposki, 2003: 23).

Tahmin edileceği üzere, Osmanlı Türkçesinde birçok yeniden çeviri söz konusudur. Özlem Berk Albachten ve Şehnaz Tahir Gürçağlar'in Perspectives on Retranslation. Ideology, Paratexts, Methods [Yeniden Çeviri Üzerine Perspektifler. İdeoloji, Yan-Metinler, Yöntemler] adlı eserde yer alan "The Making and Reading of a Bibliography of Retranslations" [Yeniden Çevirilerin Bibliyografyasının Hazırlanması ve Okunması] başlıklı çalışması bu açıdan önemli veriler sunmaktadır. Araştırmacılar söz konusu çalışmanın "Retranslations in Ottoman Script" [Osmanlı Türkçesinde Yeniden Çeviriler] adlı bölümünde Osmanlı Türkçesindeki yeniden çevirilere ışık tutmakla birlikte 14. yüzyıldan 200o'li yıllara kadar geçen sürede yapılan çevirilerin sayısal değerlendirmesini de sunar (Albachten ve Tahir Gürçağlar, 2019a: 221-230): 14. yüzyılda 33, 15. yüzyılda 93, 16. yüzyılda 259, 17. yüzyılda 253, 18. yüzyılda 251, 19. yüzyılda 295 yeniden çeviri tespit edilmiştir (age. 222). Çalışmada 20. yüzyılda 19001929 yılları arasında Arap harfleriyle yayımlanmış 147 yeniden çeviri örneğine rastlandığına, ayrıca 1928 yılında gerçekleşen Harf Devrimi dolayısıyla 1929 yılında bir duraklama yaşandığına dikkat çekilir. Bu makaledeki incelemenin kapsadığı dönem olan 1908-1928 yıllarında 147 yeniden çevirinin varlığından bahsedilir (age.). İlgili dönemde, Arsène Lupin serisinde yer alan birçok eserin dilimize çevrildiği görülmektedir. Seride yer alan Arsène Lupin, Gentleman Cambrioleur ise çevirisi en çok yapılan eserdir.

Leblanc'in Arsène Lupin maceralarını anlattı̆̆ ilk öykü "L'Arrestation d'Arsène Lupin" 1905 yllında Je sais tout adlı dergide yayımlanır. Bu ilk öykünün okurla buluşması kısaca şu şekilde anlatılabilir: Dönemin önde gelen editörlerinden Pierre Lafitte bir dergi çıkarmaya karar verir. Lafitte, arkadaşı Leblanc'dan söz konusu dergide yayımlanmak üzere polisiye bir öykü yazmasını ve İngilizlerin meşhur dedektifi Sherlock Holmes'e cevap niteliğinde Fransız bir kahraman yaratmasını ister. Leblanc'ın bu istek üzerine kaleme aldığı öykü, derginin 15 Temmuz 1905 tarihli sayısında yayımlanır. Böylece Arsène Lupin edebiyat dünyasındaki yerini almış olur (krş. Drake, 2009: 109).

"L’Arrestation d'Arsène Lupin” okur tarafından çok beğenilince Leblanc, Lafitte'in de israrıly Lupin öykülerini yazmaya devam eder. 1905-1907 yılları arasında Lupin'in farklı maceralarının anlatıldı̆̆ toplam dokuz öykü Je sais tout'da yayımlanır. Öykülerin dergideki yayımlanma sırası şu şekildedir: "L'arrestation d'Arsène Lupin" (1905), "Arsène Lupin en prison" (1905), "L'évasion d'Arsène Lupin" (1906), "Le mystérieux voyageur" (1906), "Le Collier de la Reine" (1906), "Le coffre-fort de Madame Imbert” (1906), "Herlock Sholmès arrive trop tard" (1906), "La perle noire” (1906), "Le sept de cœur" (1907). 1907 yllında söz konusu dokuz öykü Arsène Lupin, Gentleman Cambrioleur adıyla bir kitapta toplanır (Couégnas, 2016: 5).

Kahraman hakkında genel bilgi vermek gerekirse, Arsène Lupin’in bilinen hırsızlardan oldukça farklı özelliklere sahip olduğu iddia edilmektedir. Leblanc, Arsène Lupin'i “cesur ve kibar" olarak tanımlar. Lupin bir hırsızdır, hırsızlık yapar, suç işler ancak tüm bunlara rağmen okur Lupin'e kızamaz, tam aksine onu gözünde kahramanlaştırır. Lupin’i sadece bir hırsız olarak değerlendirmek doğru 
A descriptive study on the Ottoman Turkish (re)translations of Arsène Lupin, Gentleman Cambrioleur / G. Güler; A. B. Karadağ (pp. 654-682)

olmayacaktır; Lupin herhangi bir kazanç sağlama amacıyla çalmaz zira böyle bir şeye ihtiyacı yoktur. Gerçekleştirdiği eylemlerle bir bakıma adaleti sağlamaya çalışır. Çaldıklarını fakirlere dağıtır ve her zaman güçsüzlerin yanındadır. Hiçbir zaman "iyi insanlar"dan bir şey çalmaz; kurbanları arasında "saygıyı hak etmeyen" ve haksız yoldan kazanç elde etmiş zengin insanlar vardır. Bu tür insanların haksız kazançlarını çalmasının Lupin’e bir bakıma ahlaki bir meşruluk kazandırdığı söylenebilir (krş. Drake, 2009: 114).

Türk kültür ve edebiyat dizgesindeki polisiye roman örneklerine bakıldığında dilimize en çok çevrilen polisiye eserlerden olduğu görülen Arsène Lupin serisinin neredeyse Fransız kaynak dizgesi ile aynı anda Türk erek dizgesindeki yerini aldığı bilinmektedir. Lupin öyküleri Fransa'da tefrika edilmesinin üç yıl, kitap olarak yayımlanmasının ise bir yıl gibi kısa bir süre sonrasında dilimize çevrilmiştir (Üyepazarc1, 2008: 546).

Bilindiği üzere roman, Türk kültür ve edebiyat dizgesine çeviri yoluyla girmiş bir türdür. Çevirilerin ardından Türkçe kaleme alınmış telif romanlar da üretilmiş, Dil Devrimi'nden sonra ise hem yeni alfabeyle hem de çeviriyazı ve diliçi çevirilerle bu tür, yerli okur kitlesinin beğenisine sunulmuştur (krş. Karadağ, 2019: 10).

II. Meşrutiyet'in ilanının ardından I. Dünya Savaşı'na kadar geçen sürede çeviri ve yerli eser üretiminde kayda değer bir artış yaşanmış, 1914 yllında ise çeviri ve yerli eser üretimi benzeri görülmemiş bir sayıya ulaşmıştır (krş. Erkul Yağcı, 2019: 354). Ahu Selin Erkul Yağcı'ya göre, söz konusu dönemde Batı'nın etkisinde gelişmekte olan edebiyat alanında çeviri faaliyetleri önemli bir yer tutmaktaydı. 1908-1940 yılları arasında yayımlanan romanların yaklaşık yüzde ellisini çeviri eserler oluşturuyordu ve bu çeviri eserler Batılı edebî biçimleri ve konuları taklit eden birçok yerli eserin üretilmesinde "şablon" olarak kullanılmaları bakımından şekillendirici bir role sahipti (Erkul Yağcı, 2019: 358).

Türk edebiyatı için yeni bir tür olan roman, kısa sürede kendini topluma kabul ettirmiş ve geniş bir okur kitlesine ulaşmıştır. Nitekim Türk aydınları da çevirdikleri Batı romanlarından esinlenerek millî bir roman oluşturma çabasına girmiştir. Fatih Andı’nın, "konusunu yerli hayattan alan telif roman" olarak tanımladığı millî roman örnekleri çeviri romanlardan kısa süre sonra Türk edebiyat dizgesindeki yerini almıştır (krş. Andı, 1993: 11-18). Batı’nın fikir ve hayat tarzının, Türk toplumunun millî ve manevi değerlerine uygun bir şekilde, millî roman vasıtasıyla Türk okuruna sunulmasının amaçlandı̆̆ görülmektedir:

Romanı "faydalı bir eğlence" olarak değerlendiren Namık Kemal, romandaki vakanın, millî duyuş, düşünüş ve yaşayışa, kısacası milletin maddi ve manevi kültürüne ters düşmeyecek şekilde örülmesi gerektiğini söyler. [...] Bu nedenle, roman vakalarını ve kişilerini, toplumun millî değerleriyle örüp Türk okuruna sunan Tanzimat aydınları, o dönemin getirdiği şartlar neticesinde millî roman anlayışı vücuda getirirler (Tarakçı, 2010: 497).

Makalenin devam eden bölümünde öncelikle, inceleme nesnesini oluşturan Arsène Lupin, Gentleman Cambrioleur'ün beş farklı çevirisi ayrı ayrı ele alınacak ve yeniden çevirileri yan-metinsel ögeler çerçevesinde betimleyici bir çalışmayla irdelenecektir.

\subsection{Arsen Lüpen}

Arsène Lupin’in ilk çevirileri de, Batılılaşmanın gündeme geldiği dönemlerde, Batı ile çok yakın temas içerisinde olan Selanik şehrinde yapılır. Daha sonraları İzmir'de Yeni Asır adını alacak olan gazete ilk

Adres

Kırklareli Üniversitesi, Fen Edebiyat Fakültesi, Türk Dili ve Edebiyatı Bölümü, Kayalı Kampüsü-Kırklareli/TÜRKIYYE e-posta: editor@rumelide.com 
olarak 1895 yılında Selanik’te Asır adıyla basılır. Gazetenin sahibi ve başyazarı ise yazdığı telif romanlar dışında yaptığı çevirilerle de tanınan Fazlı Necip’tir (Üyepazarcı, 1997: 111). 1864-1932 yılları arasında yaşayan Fazlı Necip, romancı ve çevirmen kişiliğiyle tanınır. Avukat olmak istemesine rağmen yaşı tutmadığı için ruhsat alamaz ve basın hayatına atılmaya karar verir. Arkadaşlarıyla birlikte çıkardığı bir dergide çeşitli yazılar yayımlar. Bu derginin yanı sıra farklı alanlarda çeviri ve telif olmak üzere birçok kitap ve makalesi bulunan Fazlı Necip, ilk Arsène Lupin çevirmeni olarak bilinmektedir (krş. Yalçın, 2001: 350).

Fazlı Necip, II. Meşrutiyet'in ilanından sonraki yıllarda, Asır Matbaası'nda her ayın on beşinde bir kitap yayımlanacak şekilde Roman Hazinesi adı altında bir seri kitap yayımına başlar. Kaynak kültürde Arsène Lupin serisi için benzer bir seri adı bulunmamaktadır. Fazlı Necip’in birden çok romanı bir arada sunma düşüncesinin, kendisini erek kültürdeki söz konusu adlandırmaya sevk ettiği düşünülebilir. Nitekim bu seride sadece Arsène Lupin çevirileri değil başka çeviri ve telif romanlar da yer almaktadır. Üyepazarcı, Fazlı Necip’in ilk altı cildini Arsène Lupin maceralarına ayırdı̆̆ı Roman Hazinesi serisinin yedinci, sekizinci ve dokuzuncu ciltlerini kendi yazdı̆̆ Dehşetler İçinde adlı polisiye romana ayırdığını ifade eder (1997: 173).

Arsène Lupin, Gentleman Cambrioleur, Roman Hazinesïnin birinci cildinde yer almaktadır. Fazlı Necip bu eseri 1325 [1909] yllında Arsen Lüpen adıyla çevirir. Kaynak metindeki "Gentleman Cambrioleur" kısmının çevrilmemesi çevirmenin, kahramanın adını ön planda tutmayı amaçlaması şeklinde yorumlanabilir.

Çeviri eserin ön kapağında, Fazlı Necip’in çevirisine verdiği Arsen Lüpen başlığı ile birlikte, üst kısımda serinin adı -Roman Hazinesi- yer alırken kapakta yazar veya çevirmen adına rastlanmamaktadır (bkz. Ek 1). Roman Hazinesi serisinin diğer ciltlerine bakıldığında ise yazarın "Muharriri: Moris Löblan" (Fransızca okunduğu şekliyle), çevirmenin "Mütercimi: Fazlı Necip" şeklinde geçtiği görülmektedir (bkz. Ek 2). Diğer ciltlerde yazar ve çevirmen adı açık bir şekilde belirtilirken ilk ciltte bu bilgilerin verilmemiş olması dikkat çekicidir denebilir.

Kapaktaki Roman Hazinesi başlı̆ı̆ın altında "Her ayın on beşinde neşrolunur" bilgisi yer alır (bkz. Ek 1). Erek metnin Selanik'te Yeni Asır Matbaası'nda basıldığı belirtilmiştir. Söz konusu matbaa Asır Gazetesi’ne aittir. Kitabın fiyatının ne kadar olduğu, posta ücretiyle birlikte ne kadar olacağı ve bir yıllık abonelik için ne kadar ödeme yapılması gerektiği de kapaktaki bilgiler arasındadır (bkz. Ek 1). Ayrıca, "Bir senelik on iki cilt için abonesi üç mecidiye" ifadesiyle serinin en az on iki cilt olarak planlandığı bilgisinin de paylaşılmış olduğu görülmektedir.

Erek metinde yayınevi tarafından kaleme alınan iki ön söz bulunmaktadır. Birinci ön söz, "Roman Hazinesi” başlı̆̆ı altında yer alır. Yayınevi, bu ön sözde Asır Gazetesi’nde tefrika edilen eserleri roman hâlinde yayımlamaya karar verdiğini ve her ayın on beşinde bir cilt roman basacağını ifade etmektedir. Seride yer alacak eserlerin bazllarının daha önce gazetede basılan "millı̂" ve "tercüme" romanlar olduğu, bazılarının ise daha önce hiç basılmamış "millı̂" ve "tercüme" romanlar olacağ aktarılmaktadır. Burada altı çizilmesi gereken nokta, söz konusu metinde "millı”" ve "telif" ifadelerinin aynı anlamda kullanılmasıdır. Ayrıca, romanların fiyatları hakkında bilgilendirme yapılmaktadır. İlk cildin Arsène Lupin'e ayrılacağı da ön sözde yer alan diğer bir bilgidir:

\section{Roman Hazinesi}

Yeni Asır Matbaası [Roman Hazinesi] unvanı altında her ayın on beşinci günü bir cilt roman basmaya karar vermiştir. 
A descriptive study on the Ottoman Turkish (re)translations of Arsène Lupin, Gentleman Cambrioleur / G. Güler; A. B. Karadağ (pp. 654-682)

Bu romanlar kısmen gazetemizde daha önce tefrika edilmiş ve henüz kitap şeklinde basılmamış olan millî ve tercüme romanlardan oluşacak bir kısmını ise gazetemizde tefrika edilmemiş yeni millî ve tercüme romanlar oluşturacaktır.

Roman Hazinesi başyazarımızın kaleme aldığı romanları toplayacaksa da diğer yazarlarımızın telif ve tercüme güzel eserlerini de içerebilecektir.

Romanların üç yüz sayfalık bir cildini beş kuruşa satışa çıkaracağız. Dışarıya posta ücretiyle beraber altı kuruşa gönderilecektir.

Dışarıdan, bir senelik on iki cilt romana abone olmak isteyenler matbaamıza üç mecidiye gönderirlerse her cildi derhâl gönderilir.

Roman Hazinesi’nin birinci cildi Arsen Lüpen romanını içeriyor (bkz. Ek 3).

"Mukaddime" başlıklı ikinci ön sözde eserlerde yer alan kahramanların olağanüstü özelliklerine değinilirken Arsène Lupin'e de özel bir vurgu yapılır. Arsène Lupin'den ve onun maceralarından övgüyle söz edilir. Yayınevinin okurda merak uyandıracak cümlelere başvurduğu, okurun ilgisini çekmeye çalıştığı görülmektedir. Sadece kitap kapağına veya ön söze bakıp kitabı almaya karar verecek okurları etkilemek için böyle bir politika izlendiği iddia edilebilir. Ayrıca yayınevi, Arsène Lupin tefrikalarının ilgiyle karşlanmasının, Roman Hazinesi’nin birinci cildinin söz konusu esere ayrılmasında etkili olduğunu ifade eder. Çevirisi yapılacak eserin daha önce kaynak kültürde tanınmış ve rağbet görmüş olması da eser seçimindeki önemli etkenler arasında sayılabilir. Bu nedenle yayınevinin böyle bir yola başvurduğu düşünülebilir:

Mukaddime

Romanın ilerlemesi her konuda artar. Böylelikle birçok konuda olağanüstü eserler görüldüğü gibi, hırsızlar ve serseriler arasında da dâhi denecek derecede üstün zekâ sahiplerine rastlamak mümkündür. Bunların -deyim yerindeyse- mesleklerinde yarattıkları harikalar herkesi hayretler içinde bırakır. Bu eserde türlü garip işleri anlatılan Arsen Lüpen’i de yukarıda değindiğimiz olağanüstü kişilerin başında sayabiliriz.

Gazetemizde tefrika ettiğimiz bu romanların gördüğü olağanüstü ilgi yayımına başladı̆̆ımız Roman Hazinesi’nin birinci cildini Arsen Lüpen'e ayırma konusunda bize cesaret verdi (bkz. Ek 4).

Ön sözde, Roman Hazinesi’nin ilk cildinin Arsène Lupin'e ayrıldığı ifade edilse de okurdan gelen talep neticesinde serinin altı cildi Arsène Lupin çevirilerine ayrılır. Ancak eldeki Arsène Lupin öyküleri tükenince başka eserler yayımlanabilir (Üyepazarcı, 2008: 547).

Ön sözde ayrıca romanın gelişiminden ve bu gelişimle birlikte her tarzda eserin verilmeye başlandığından bahsedilir. Romanın gelişiminin konu çeşitliliğini de beraberinde getirdiği düşünülmektedir. Tanzimat'tan II. Meşrutiyet'e kadar Batı dillerinden Osmanlı Türkçesine fennî roman, tarihî roman, cinai roman gibi farklı türlerde roman çevirileri yapıldığı bilinmektedir (krş. Karadă̆, 2012: 45). İlk çeviri romanlardan çok kısa bir süre sonra polisiye roman örnekleri görülür. Osmanlı Dönemi’ndeki ilk polisiye roman örneğinin Ahmet Mithat Efendi tarafından kaleme alınan Esrâr-ı Cinayât adlı eser olduğu bilinmektedir. Özellikle II. Meşrutiyet’in ilanından sonra sansürün kaldırılmasıyla fasikül hâlinde çok sayıda polisiye roman ve hikâye yayımlandığına dikkat çekilmektedir (krş. Şahin, 2011: 16).

Ele alınan kaynak metin 264 sayfadan oluşurken erek metin 224 sayfadır. Bu noktada kitap boyutlarındaki ve alfabedeki farklılıklar göz önünde bulundurulmalıdır. Fazlı Necip’in, kaynak metinde yer alan toplam dokuz öyküden yedisini çevirdiği görülmektedir (bkz. Tablo 1).

Tablo 1

Kırklareli Üniversitesi, Fen Edebiyat Fakültesi, Türk Dili ve Edebiyatı Bölümü, Kayalı Kampüsü-Kırklareli/TÜRKİYE e-posta: editor@rumelide.com
Address

Kırklareli University, Faculty of Arts and Sciences, Department of Turkish Language and Literature, Kayalı Campus-Kırklareli/TURKEY e-mail: editor@rumelide.com 


\begin{tabular}{|c|c|c|}
\hline & $\begin{array}{l}\text { Maurice Leblanc, } 1907 \\
\text { Arsène Lupin, Gentleman Cambrioleur }\end{array}$ & $\begin{array}{l}\text { Fazlı Necip, } 1325 \text { [1909] } \\
\text { Arsen Lüpen }\end{array}$ \\
\hline 1. & "L'arrestation d'Arsène Lupin" (4-24) & “Arsen Lüpen” (5-27) \\
\hline 2. & "Arsène Lupin en prison" (25-54) & "Arsen Lüpen Hapiste” (28-6o) \\
\hline 3. & “L'évasion d'Arsène Lupin" (55-84) & “Arsen Lüpen Firar Eder” (61-10o) \\
\hline 4. & "Le mystérieux voyageur" (85-108) & "Acayip Bir Yolcu” (101-130) \\
\hline 5 . & "Le Collier de la Reine" (109-133) & "Kraliçe Gerdanlı̆̆ı" (131-156) \\
\hline 6. & “Le sept de cœur" (134-187) & Çevrilmemiş \\
\hline 7. & “Le coffre-fort de Madame Imbert" (188-204) & Çevrilmemiş \\
\hline 8. & "La perle noire" (205-225) & "Siyah İnci” (202-224) \\
\hline 9. & "Herlock Sholmès arrive trop tard" (226-263) & "Herlok Şolmz Geç Yetişti" (157-201) \\
\hline
\end{tabular}

Tablo 1'de görüldüğü gibi, çevirisi yapılmayan iki öykü "Le sept de cœur" ve "Le coffre-fort de Madame Imbert” başlıklı öykülerdir. Çevirisi yapılan öykülerin başlıklarına bakıldığında, kaynak metne yakın bir yol izlendiği, özel isimlerin ise okunduğu şekliyle verildiği söylenebilir. Birinci öykünün "L'arrestation d'Arsène Lupin" şeklindeki başlığını "Arsen Lüpen'in Tutuklanması" yerine sadece "Arsen Lüpen” olarak çevirmeyi tercih ettiği görülen çevirmenin, söz konusu başlıktaki "l'arrestation" ifadesini çevirmeyi uygun bulmadığı düşünülebilir.

\subsection{Sarik Arsen Lüpen}

Arsène Lupin, Gentleman Cambrioleur'ün ikinci çevirisi 1325 [1909] yllında Osman Vefik tarafından yapılır. Osman Vefik'in ilk Arsèn Lupin çevirileri, Ahmet Mithat Efendi'ye ait Tercüman-ı Hakikat Gazetesinnde tefrika edildikten sonra yine Ahmet Mithat Efendi'ye ait Tercüman-ı Hakikat Matbaası'nda basılır (Üyepazarcı, 1997: 115). TDV İslâm Ansiklopedisi’nde, Tercüman-ı Hakikat'in II. Abdülhamit Dönemi'nde 1878'de yayın hayatına başladığı, gazetede telif romanlar tefrika edildiği gibi Batı klasiklerinin ve Batı dünyasındaki gelişmelerin de yer aldığı bilgisi bulunur. Ayrıca, Tercüman-ı Hakikat Matbaası'nda gazetede daha önce tefrika edilen edebiyat, tarih, felsefe ve bilim alanındaki seri yazıların ve bazı çeviri yazıların basıldığı ifade edilir (krş. Tekin, 2011: 497-498).

Seyfettin Özege kataloğunda Osman Vefik'e ait olduğu düşünülen Polisin Tatbikat-ı Adliyesi adlı bir eser bulunmaktadır. Osman Vefik, "İfade" başlıklı ön sözde söz konusu eserin Beyrut Polis Mektebi’nde geçen üç dönemlik eğitimin ürünü olduğunu dile getirmektedir (bkz. Ek 5). Ayrıca, eserin son sayfasında aynı yazara ait yayımlanmış ve yayımlanacak olan Rehber-i Muamelat-ı Zabıta, Polisin Tatbikat-ı İdariyesi ve Polisin Tatbikatı Malumat-ı Kanuniyesi adlı kitapların bilgisi verilir (bkz. Ek 6). Bu bilgiden hareketle Osman Vefik'in Arsène Lupin çevirilerinin yanı sıra polisiye roman üzerine yazdığı telif eserlerinin de olduğu söylenebilir.

Osman Vefik, Arsène Lupin, Gentleman Cambrioleur'ü Sarik Arsen Lüpen adıyla çevirmiştir. Çevirmenin, kaynak metindeki "Cambrioleur"ü "Sarik" olarak çevirdiği, "Gentleman” ise çevirmediği görülmektedir. Bu durum, çevirmenin başlıkta Arsène Lupin’in hırsız yönünü vurgulamayı tercih ettiği ancak "kibar/centilmen/beyefendi” yönüne işaret etmeyi uygun görmediği şeklinde yorumlanabilir.

İncelenen erek metinde iki kapak bulunmaktadır. Bu kapaklar, dış kapak ve iç kapak olarak değerlendirilecektir. Dış kapağın en üst kısmında eserin yer aldığı serinin adı görülür: "Tercüman-ı 
Hakikatin: ‘Âsâr-ı Müntahabe’ Kütüphanesi” (bkz. Ek 7). Bu yazının hemen alt satırında eserin birinci kitap olduğu bilgisi mevcuttur. Eserin kaynak dildeki başlı̆̆ı kapakta bulunmaz ancak erek dildeki başlığı kapağın orta kısmında, "Sarik" ve onun alt satırında koyu yazılmış “Arsen Lüpen” şeklinde verilir. Osman Vefik “Mütercimi” şeklinde geçerken kaynak eser yazarının adına rastlanmaz.

Dış kapakta, eserin Tercüman-ı Hakikat Gazetesi’nde tefrika edildikten sonra kitap şeklinde basıldı̆̆ı ve fiyatının bir kuruş olduğu bilgisi yer alır (bkz. Ek 7). Kapağın en alt kısmında ise baskının 1325 [1909] yllında Dersaadet’te yapıldığı yazar. İç kapakta da dış kapaktaki bilgilerin aynısı verilmiştir. Sadece "Arsen Lüpen” yazısı dış kapağa göre daha büyük punto ile koyu ve süslü bir şekilde yazılmıştır (bkz. Ek 8). Erek metinde ön söz veya son söz bulunmamaktadır.

Erek metin, toplamda 43 sayfadan oluşmaktadır. Çevirmenin, kaynak metindeki dokuz öyküden ikisini çevirdiği görülmektedir (bkz. Tablo 2).

Tablo 2

\begin{tabular}{|c|c|c|}
\hline & $\begin{array}{l}\text { Maurice Leblanc, } 1907 \\
\text { Arsène Lupin, Gentleman Cambrioleur }\end{array}$ & $\begin{array}{l}\text { Osman Vefik, } 1325 \text { [1909] } \\
\text { Sarik Arsen Lüpen }\end{array}$ \\
\hline 1. & “L'arrestation d’Arsène Lupin” (4-24) & Çevrilmemiş \\
\hline 2. & “Arsène Lupin en prison” (25-54) & Çevrilmemiş \\
\hline 3. & “L'évasion d'Arsène Lupin” (55-84) & Çevrilmemiş \\
\hline 4. & “Le mystérieux voyageur” (85-108) & “Garip Bir Yolcu” (3-20) \\
\hline 5. & "Le Collier de la Reine" (109-133) & Çevrilmemiş \\
\hline 6. & "Le sept de cœur" (134-187) & "Kupa Yedilisi” (21-43) \\
\hline 7. & “Le coffre-fort de Madame Imbert” (188-204) & Çevrilmemiş \\
\hline 8. & "La perle noire" (205-225) & Çevrilmemiş \\
\hline 9. & “Herlock Sholmès arrive trop tard” (226-263) & Çevrilmemiş \\
\hline
\end{tabular}

Tablo 2'de görüldüğü gibi, "L'arrestation d'Arsène Lupin", "Arsène Lupin en prison", "L'évasion d'Arsène Lupin", "Le Collier de la Reine", "Le coffre-fort de Madame Imbert", "La perle noire", "Herlock Sholmès arrive trop tard" başlıklı öyküler çevrilmemiştir. Çevirisi yapılan "Le mystérieux voyageur" ve "Le sept de cœur" öykülerinin erek dildeki başlıklarına bakıldığında, çevirmenin genel olarak kaynak metne yakın bir tercih yaptı̆̆ iddia edilebilir.

\subsection{Arsen Lüpen Hem Kibar! Hem Horsız!!!}

Arsène Lupin, Gentleman Cambrioleur'ün ikinci yeniden çevirisi 1333 [1917] yllında Süleyman Tevfik (1861-1939) tarafından yapılır. Bu çeviri dönemin tanınmış yayınevlerinden olan Cemiyet Kütüphanesi'nden çıkar. Cemiyet Kütüphanesi polisiye yayınlarda uzmanlaşmış, birçok polisiye roman yayını olan bir kurum olarak bilinmektedir. Üyepazarcı, o dönemlerde yayımlanan bazı polisiye kitapların arkasında Cemiyet Kütüphanesi yayınlarının listesinin bulunduğunu ifade eder (2008: 164). Cemiyet Kütüphanesi'nin Arsène Lupin çevirileri dışında o dönem çok popüler olan başka polisiye eserleri de yayımladığı görülmektedir (age. 152, 164, 182, 186).

Süleyman Tevfik hem telif hem de çeviri eserleriyle döneminin önemli yazarları arasında yer alır. İyi bir öğrenim gören Süleyman Tevfik Arapça, Farsça, İtalyanca ve Fransızca öğrenir. Halep’te icra ettiği Fransızca öğretmenliğinin yanı sıra Selanik’te çeşitli memurluklarda bulunur. Üretken bir yazar olarak

\footnotetext{
Adres | Address 
değerlendirilen Süleyman Tevfik’in din, edebiyat, folklor, tarih, yemek ve dil üzerine 150'den fazla telif ve çeviri eseri bulunduğu bilinmektedir (Yalçın, 2001: 752).

Süleyman Tevfik polisiye roman çevirilerinin yanı sıra tarihî roman ve çocuk edebiyatı alanında da önemli çeviriler yapmıştır. Eshabil Bozkurt ve Ayşe Banu Karadağ’ın (2014) birlikte kaleme aldığı “Türk Kültür ve Edebiyat Dizgesinde Çok Kimlikli Bir Mütercim: Süleyman Tevfik” adlı makalede, çok yönlü bir kişiliğe sahip olan Süleyman Tevfik’in Türk çeviri tarihindeki yerine ve önemine değinilmiştir. Süleyman Tevfik, birden çok yabancı dil bilmesi sayesinde Batı dillerinden Osmanlı Türkçesine çeviri yoluyla birçok eser kazandırmış ve bu yönüyle Türk edebiyat tarihinde önemli bir yer edinmiştir. Süleyman Tevfik’in yaşadığı dönemin popüler türü olan polisiye roman alanında birçok çevirisi bulunmaktadır. Özellikle de Arthur Conan Doyle ve Maurice Leblanc'dan çeviriler yaptı̆̆ görülmektedir:

\begin{abstract}
Mütercimin dönemin modası olarak kabul edilebilecek roman türü olan polisiye roman sahasında da çeviriler yaptığı görülmektedir. Nik Karter, Arsen Lüpen ve Şarlok Holmes gibi polisiye serilerden çeviriler yapan mütercimin kaynak yazarları arasında Arthur Conan Doyle ve Maurice Leblanc isimleri ön plana çıkmaktadır. Mütercimin bu roman türündeki çeviri eserleri şunlardır: Şarlok Holmes (Mak Karney Cinayeti - Zengin Dilenci - Halanın Milyonlar - Prensin Elmasları), Otel Sofracıbaşısının Feraseti, Nik Karter, Güzel Kraliçenin İdamı, Arabacının Cinayeti, Arsen Lüpen Hem Kibar Hem Hirsız (Bozkurt ve Karadağ, 2014: 49).
\end{abstract}

Süleyman Tevfik, Arsène Lupin, Gentleman Cambrioleur'ü Arsen Lüpen Hem Kibar! Hem Hirsız!!! adıyla çevirir. Bu bağlamda çevirmenin kaynak eserin adına yakın bir çeviriyi tercih ettiği söylenebilir. Arsène Lupin hem hırsız hem de iyi bir kahramandır. Her zaman kibar ve esprili bir mizaca sahip olan Lupin, maceralarında hiçbir zaman silah kullanmaz, kandan nefret eder; zenginden alıp yoksula dağıtan bir kahraman özelliklerini taşır. Hırsızlığının yanı sıra beyefendi kişiliği ile tanınır. Bu yönüyle, meslektaşlarından ayrılır ve popülerliğe kavuşur (krş. Üyepazarcı, 2008: 84). Süleyman Tevfik’in, başlığın çevirisindeki bu tercihiyle kahramanın kaynak kültürde en bilinen özelliğini öne çıkarmayı amaçladığ iddia edilebilir.

Erek metnin ön kapağında, sağ üst köşede Süleyman Tevfik mütercim olarak belirtilir, buna karşın kaynak metnin yazarına rastlanmaz. Kapakta, eserin kaynak dildeki adı paylaşılmamış, sadece erek dildeki adına yer verilmiştir (bkz. Ek 9). Eserin adının hemen altında şu cümle yazar: "Dünyanın en kibar ve en şık ve en müthiş hırsızı (Arsen Lüpen)in harikulâde ve heyecanlı son macerasını içeren romandır.” Söz konusu cümleyle, Arsène Lupin’in dünya üzerindeki popülerliğine gönderme yapılarak okurda eserle ilgili merak uyandırmanın amaçlandığı düşünülebilir. Kapağın en alt kısmında baskının Kader Matbaası'nda 1333 [1917] yılında yapıldı̆̆ı bilgisi yer alır (bkz. Ek 9). Erek metinde ön söz veya son söz bulunmamaktadır.

Süleyman Tevfik’in, kaynak metindeki tüm öykülerin çevirisini yaptı̆̆g görülmektedir (bkz. Tablo 3).

Tablo 3

\begin{tabular}{|l|l|l|}
\cline { 2 - 3 } \multicolumn{1}{l|}{} & $\begin{array}{l}\text { Maurice Leblanc, } 1907 \\
\text { Arsène Lupin, Gentleman Cambrioleur }\end{array}$ & $\begin{array}{l}\text { Süleyman Tevfik, 1333 [1917] } \\
\text { Arsen Lüpen Hem Kibar! Hem Horszz!!! }\end{array}$ \\
\hline 1. & "L'arrestation d'Arsène Lupin” (4-24) & “Arsen Lüpen'in Tevkifi” (3-24) \\
\hline 2. & “Arsène Lupin en prison” (25-54) & “Arsen Lüpen Hapiste” (25-56) \\
\hline 3. & "L'évasion d'Arsène Lupin" (55-84) & “Arsen Lüpen Kaçıor” (57-89) \\
\hline 4. & "Le mystérieux voyageur” (85-108) & “Esrarengiz Yolcu” (90-115) \\
\hline
\end{tabular}


A descriptive study on the Ottoman Turkish (re)translations of Arsène Lupin, Gentleman Cambrioleur / G. Güler; A. B. Karadağ (pp. 654-682)

\begin{tabular}{|l|l|l|}
\hline 5. & "Le Collier de la Reine” (109-133) & "Kraliçenin Gerdanlı̆̆ı" (116-143) \\
\hline 6. & "Le sept de cœur" (134-187) & "Kupa Yedilisi” (144-196) \\
\hline 7. & "Le coffre-fort de Madame Imbert” (188-204) & "Madam İmber’in Kasası" (197-211) \\
\hline 8. & "La perle noire” (205-225) & "Siyah İnci” (212-230) \\
\hline 9. & "Herlock Sholmès arrive trop tard” (226-263) & "Herlok Şolmz Geç Kaldı" (231-256) \\
\hline
\end{tabular}

Çevirisi yapılan öykülerin başlıklarına bakıldığında, çevirmenin genel olarak kaynak metne bağlı kalmayı tercih ettiği söylenebilir.

\subsection{Arsen Lüpen Hapishanede}

1341 [1925] yllına gelindiğinde yeni bir Arsène Lupin, Gentleman Cambrioleur çevirisinin yayımlandığı görülür. Eser, dönemin yazar ve çevirmenlerinden Mustafa Remzi’ye aittir ve daha önce belirtildiği gibi bahsi geçen dönemde özellikle yayımladığı polisiye roman türündeki eserler ile tanınan Cemiyet Kütüphanesi’nden çıkar.

Mustafa Remzi, Arsène Lupin ve Nat Pinkerton çevirmeni olarak tanınır. Polisiye roman çevirilerinin yanı sıra çŏ̆u erotik içeriğe sahip öyküler kaleme aldığı bilinmektedir. Bu öykülerinden bazıları Günahsız Kadınlar, Postacı Kı, Öldüren Dans, Dul Kadının Esrarı, Gelin Hanım, Günahsız Fahişe, Çapkın Kız ve Genç Mektupları'dır (Üyepazarcı, 2008: 571).

Seyfettin Özege kataloğu tarandığında, Mustafa Remzi'nin birçok Arsène Lupin çevirisi yaptığı görülmektedir. Üyepazarcı da incelemesinde, Mustafa Remzi'nin iki seri hâlinde Arsène Lupin çevirisine imza attı̆̆ını ifade eder. İlk seride, Arsen Lüpen Hapishanede, Arsen Lüpen Kadın Hırsızı, Arsen Lüpen Parisin Yer Altında, Arsen Lüpen Kadınlar Arasında, Arsen Lüpen Kumar Masasinda, Arsen Lüpen Kadınlar Katili, Esrarengiz Çanta ve Arsen Lüpen’in İzdivacı adlı eserler, ikinci seride ise Arsen Lüpen ve Sherlock Holmes, Salon Cinayeti, Balo Cinayeti ve Arsen Lüpen Sherlock Holmes’in Pençesinde adlı eserler yer almaktadır (krş. Üyepazarcı, 1997: 120). Makale kapsamında sadece Arsen Lüpen Hapishanede adlı eser ele alınacaktır.

Makalenin inceleme nesnesini oluşturan Arsène Lupin, Gentleman Cambrioleur, Seyfettin Özege kataloğunda Mustafa Remzi'nin Arsen Lüpen serisinde yer alan ikinci kitap olarak görülmektedir. Mustafa Remzi’nin çevirisine kaynak metnin ikinci öyküsü olan "Arsène Lupin en prison"dan hareketle Arsen Lüpen Hapishanede adını verdiği düşünülebilir.

Ön kapakta Mustafa Remzi, "nâkili”9 şeklinde belirtilirken, kaynak metnin yazarının adına rastlanmaz. Kapakta eserin sadece erek dildeki adı görülür (bkz. Ek 10). Kapaktaki bilgiye göre eser, İstanbul'da Suhulet Matbaası'nda 1341 [1925] yılında basılmıştır.

Arsen Lüpen Hapishanede başlıklı erek metindeki olay "Provans" adlı bir transatlantik gemisinde geçer. Bu gemi, içinde Arsène Lupin'in de bulunduğu bir yolcu grubunu Amerika'ya taşır. Arsène Lupin'in gemide olduğu bilgisi bir telgrafla yolculara iletilir. Ancak Arsène Lupin’in eşkâlinin bildirildiği sırada elektrik kesilir ve telgraf yarıda kalır. Bu durum tüm yolcuları endişeye sevk eder. Seyahat esnasında kaptanın saati Arsène Lupin tarafından çalınır. Yolculuğun sonunda polis şefi Monsieur Ganimard, Arsène Lupin'i tutuklar ve hapishaneye götürür. Öykü Arsène Lupin’in bir gece

9 Osmanlı'da metin üretme pratikleri bağlamında bkz. Demircioğlu, 2005 ve 2009; Paker, 2014. 
hapishaneden kaçması ve Paris'e gitmesiyle son bulur. Çeviri metnin kapağında, etrafı çerçevelenmiş bir kutucuğun içerisinde metinde yer alan olaylarla ilgili kısaltılmış ifadelerin okura sunulduğu görülmektedir:

Denizle Gök Arasında ... Büyük Bir Vapur ... Seyahat Âlemi .. Mis Nelli ile Korta .. Esrarengiz Bir Telsiz Telgraf .. Arsen Lüpen Gemide ... Arsen Lüpen Kim? ... Yapılan Hırsızlıklar ... Kaptanın Saati Kimin Cebinde? . Bir Gece Sabaha Karşı ... Boğuk İniltiler ... Soyulan Adam .. Arsen Lüpen’in Kart Viziti ... On Bin Frank .. Polis Hafiyesi Ganimar .. Arsen Lüpen Benim .. (bkz. Ek 10).

Erek metinde ön söz veya son söz bulunmamakta, ön kapaktaki bilgilerden sonra doğrudan öyküye geçilmektedir. "Tevkif" adlı tek bir öyküden oluşan erek metnin Mustafa Remzi tarafından kaynak metindeki ilk üç öyküden ("L'arrestation d'Arsène Lupin", "Arsène Lupin en prison", "L'évasion d'Arsène Lupin”) hareketle üretildiği söylenebilir. Mustafa Remzi’nin çevirisine verdiği ad bağlamında ise kaynak metnin birinci öyküsü “L’arrestation d'Arsène Lupin”den esinlendiği düşünülebilir.

Tablo 4

\begin{tabular}{|c|c|c|}
\hline & $\begin{array}{l}\text { Maurice Leblanc, } 1907 \\
\text { Arsène Lupin, Gentleman Cambrioleur }\end{array}$ & $\begin{array}{l}\text { Mustafa Remzi, } 1341 \text { [1925] } \\
\text { Arsen Lüpen Hapishanede }\end{array}$ \\
\hline 1. & "L'arrestation d'Arsène Lupin" (4-24) & \multirow{3}{*}{ “Tevkif” (3-30) } \\
\hline 2. & "Arsène Lupin en prison" (25-54) & \\
\hline 3. & "L'évasion d'Arsène Lupin" (55-84) & \\
\hline 4. & "Le mystérieux voyageur" (85-108) & Çevrilmemiş \\
\hline 5. & "Le Collier de la Reine" (109-133) & Çevrilmemiş \\
\hline 6. & "Le sept de cœur" (134-187) & Çevrilmemiş \\
\hline 7. & "Le coffre-fort de Madame Imbert" (188-204) & Çevrilmemiş \\
\hline 8. & "La perle noire" (205-225) & Çevrilmemiş \\
\hline 9 . & "Herlock Sholmès arrive trop tard" (226-263) & Çevrilmemiş \\
\hline
\end{tabular}

Kaynak metindeki "L'arrestation d'Arsène Lupin" adlı birinci öyküde Arsène Lupin'in tutuklanması, "Arsène Lupin en prison" adlı ikinci öyküde Arsène Lupin'in hapishanede kaldığı sürede yaşadıkları, "L'évasion d'Arsène Lupin" adlı üçüncü öyküde ise Arsène Lupin'in hapishaneden kaçışı anlatılmaktadır. Erek metinde başlık olarak tercih edilen "tevkif" kelimesi tutuklama anlamına gelmektedir ve kaynak metinde sadece birinci öykünün konusu ile bağlantılıdır. İkinci ve üçüncü öyküde farklı olaylar konu edilse de Mustafa Remzi’nin "Tevkif” başlı̆̆ını kaynak metindeki ilk üç başlığı kapsayacak şekilde kullanmayı tercih ettiği görülmektedir.

Üyepazarcı, Mustafa Remzi’nin Arsène Lupin çevirilerini şu sözlerle değerlendirir:

Mustafa Remzi’nin ilk seride Lupin öykülerini keyfine göre kısaltarak, bazen de özgün öyküde olmayan başka bölümler ekleyerek yeniden kaleme aldığı; bazen de iki öyküyü bir kitapta birleştirdiği, bu arada okuyucuya çekici gelsin diye kitap adlarında kadın sözcü̆üünü bol bol kullandığı anlaşılmaktadır. [...] Sonuç olarak ilk seri için Mustafa Remzi'nin Lupin öykülerini canının istediği gibi kesip biçip bir dizi yaptığı, bu arada araya kendi üretimi olaylar da kattığı söylenebilir (2008: 550).

Mustafa Remzi'nin Arsen Lüpen Kadın Hirsızı, Arsen Lüpen Kadınlar Arasında, Arsen Lüpen Kadınlar Katili gibi "kadın" sözcüğünü sıkça kullandığı eserleri mevcuttur. Ancak sayllan eserlerin hiçbiri kaynak kültürde bulunmamaktadır. Üyepazarcı da söz konusu eserlerin hiçbirinin Leblanc’ın 
A descriptive study on the Ottoman Turkish (re)translations of Arsène Lupin, Gentleman Cambrioleur / G. Güler; A. B. Karadağ (pp. 654-682)

özgün yapıtları olmadığını söyler. Mustafa Remzi’nin ürettiği kitaplarda “kadın” sözcüğünün bu kadar sık kullanılmasındaki amacın okurun ilgisini çekmek olduğunu iddia eder (krş. Üyepazarcı, 2008: 550). Daha önce ifade edildiği gibi Mustafa Remzi erotik içerikli telif eserlere imza atmıştır. Arsène Lupin çevirilerinde de kahramanın çapkınlığının ön plana çıkarılması, kadın imgesine sık sık vurgu yapılması bununla ilişkilendirilebilir.

Yukarıda da belirtildiği üzere, ön kapakta Mustafa Remzi eserin "nâkili” olarak gösterilmiştir. Ele alınan eserlerin sağlıklı bir şekilde değerlendirilebilmeleri için tarihsel ve bağlamsal bir yaklaşım benimsemek gerektiği tartışılmazdır. Salt çeviriler üzerine betimleme yapmayı hedefleyen bu makalenin amacını ve kapsamını aştı̆̆ı düşünülen bu önemli konuyla ilgili kaleme alınmış farklı çalışmalar mevcuttur.10 Örneğin Saliha Paker, "Terceme, Te’liff ve Özgünlük Meselesi” adlı çalışmasında "terceme" kavramının "Osmanlı kültürüne bağlı birçok aktarım çeşidini içeren pratikler bütünü” (2014: 68) olduğunu vurgular. "Terceme”nin dilden dile bir aktarım olmakla birlikte terceme eden kişinin kararıyla genişletilerek veya eksiltilerek üretilen bir yeniden yazma pratiği olduğuna dikkat çeker (krş. Paker, 2014: 42). Bu çerçevede, Osmanlı Türkçesindeki metinlerin sınıflandırılmasında "te'lîf" eser anlayışının da günümüzdeki "özgün" eser anlayışından farklı olduğu, söz konusu kavramın "yabancı sayllabilecek kaynak ya da kaynaklara dayanan, kısmen terceme olabilen, kısmen yazarın katkılarıyla üretilen” (age. 38) eser olarak tanımlandığı görülür. Bu nedenle geçmişteki çeviri çalışmaları incelenirken çevirilerin üretildikleri zamanın çeviri kavramları, anlayışları ve beklentilerinin göz önünde bulundurulması gerekliliği üzerinde durulur (krş. Demircioğlu, 2008: 238). Ayrıca Agâh Sırrı Levend'in "Eski edebiyatımızda 'terceme', bugünkü 'çeviri'yi aşan geniş bir anlam taşır" (Levend, 1988 aktaran Paker 2014: 41) sözünden de hareketle "terceme" ve "çeviri" kavramlarının farklı tanımlara sahip olduğu gözetilmelidir.

Anılan çalışmasında Paker, bu bölümde incelenen çeviride de geçen "nakl”"1in, Osmanlı edebiyatında "te'lîf" ile ilişkilendirildiğini ifade eder. Muallim Nâci'ye göre "nakl"in, "bir şairin metnini veya metninde parçaları bir başka şairin biraz değiştirerek kullanması" anlamına geldiğini ve "şair[in] bu metni veya metin parçasını kendisinin saymada bir sakınca görme[diğini]" belirtir (Paker, 2014: 5556). Bu tanım aracılığıyla bir tür sahiplenme biçimi olarak betimlenen "nakl" ile "te'lîf" arasındaki ilişki ortaya konur.

Cemal Demircioğlu, "nakl olarak terceme" konusunda Osmanlıca sözlüklerde "nakl" kelimesinin tercümeyi karşlayan bir terim olduğunu ifade eder ve bu kelimeyi çeşitli Osmanlıca sözlüklerdeki anlamları üzerinden örneklendirir (2009: 161-162). Dönemin sözlüklerindeki tanımların da "nakl" ve "tercüme" arasındaki yakın ilişkiye işaret ettiğini ve bu terimlerin tercümeyi karşılayan iki temel kavram olduğunu doğruladığını söyler (Demircioğlu, 2003: 16).

Dönemin sözlükçülerinden Şemsettin Sami, Kamus-ı Türkî'deki "terceme" maddesinde, "Bir lisandan diğer bir lisana çevirme, nakl. Harfiyyen terceme: Hiçbir kelimesini bırakmaksızın. Mealen terceme: Yalnız mealini alıp, diğer tabirâtla ifade" (2009: 395) şeklinde bir tanımlama yapar. Aynı sözlükte, "nakl" teriminin, "bir yerden bir yere götürme, diğer mahale geçirme, taşıma; [...] bir lisandan diğer bir lisana geçirme, terceme” (age. 1469) olarak tanımlandı̆̆ı görülmektedir.

\footnotetext{
$10 \quad$ Bu konudaki çalışmalara örnek olarak bkz. Demircioğlu, 2003 ve 2009; Altıntaş-Karadağ, 2019b; Baydere-Karadağ 2019.

11 "Nakl” terimiyle ilgili çalışmalara örnek olarak bkz. Demircioğlu, 2003, 2005 ve 2009; Paker, 2014.

Adres

Kırklareli Üniversitesi, Fen Edebiyat Fakültesi, Türk Dili ve Edebiyatı Bölümü, Kayalı Kampüsü-Kırklareli/TÜRKIYE e-posta: editor@rumelide.com

Address

Kırklareli University, Faculty of Arts and Sciences, Department of Turkish Language and Literature, Kayalı Campus-Kırklareli/TURKEY e-mail: editor@rumelide.com
} 
Yine dönemin ünlü sözlükçülerinden Ali Seydi’nin Kamus-ı Osmanî adlı eserinde "nakl”, "bir şeyi bir yerden kaldırıp başka bir yere götürmek; rivayet, hikâye etmek; bir şeyin suretini çıkarma, terceme etme, bir lisandan diğer lisana çevirme" (1330 [1911]: 1062) şeklinde tanımlanır.

Sonuç olarak Mustafa Remzi’nin yaptı̆̆ Arsène Lupin çevirilerinde kaynak metnin yazarının belirtilmediği, kendisinin ise "nakl" kelimesinden türetilmiş, "taşıyan, bir yerden bir yere götüren, nakil ve rivayet eden" (Şemsettin Sami, 2009: 1450) anlamlarına gelen "nâkil" olarak adlandırıldığı görülmektedir. Ayrıca, diğer bir Arsène Lupin çevirisi olan Kadınlar Katili adlı kitapta da Mustafa Remzi eserin "nâkili" olarak geçmektedir. Aynı eserin tanıtım yazısında yayınevinin "Görülmemiş bir rağbete mazhar olan 'Arsen Lüpen' sergüzeştlerinin en yenileri memleketimizin genç ve muktedir muharrirlerinden Mustafa Remzi Bey tarafından lisânımıza nakledilmektedir” sözleri yer almaktadır (bkz. Ek 11).

\subsection{Arsen Lüpen'in Sergüzeştleri}

Yeniden çeviri kapsamında incelenecek son çeviri Hasan Bedreddin'e (1870-1926) aittir. Hasan Bedreddin, Arsène Lupin, Gentleman Cambrioleur'ün çevirisini 1926 yllında yapar ve bu çeviri dönemin dergilerinden Haftalık Mecmua'nın yayımladığı kitapların ikinci sırasında yer alır.

Hasan Bedreddin de Mustafa Remzi gibi, incelenen erek metinde "nâkil" olarak tanımlanır. Hasan Bedreddin, II. Meşrutiyet sonrası dönemin hem yazar hem de çevirmen olarak bilinen isimlerinden biridir. Bizans (1913), İtalya Nedir? (1913), Mehlika Sultan (1913), Saf ve Hain (1918), Canl İğne (1926) gibi telif eserleri ve polisiye romanları dışında Manon Lescault, Casanova'nın Hatıraları gibi çevirileri vardır. Ayrıca, "Hasan Merzuk" takma adıyla da çeviriler yaptığı bilinmektedir (Üyepazarcı, 1997: 105).

Hasan Bedreddin hem kendi çevirdiği romanlarla hem de müştereken yaptı̆̆ı çevirilerle döneminin önde gelen çevirmenleri arasındadır. Hilmi Ziya Ülken, Hasan Bedreddin’in yaptığı çevirileri “[...] Hususi tercüme yapanları iki zümreye ayırmamız lazımdır: Birincisi, Garp’tan tamamıla popüler ve sırf kütle için eserler tercüme edenlerdir ki bunların başında Hasan Bedreddin ve Avan-zâde M. Süleyman'ı saymak icap eder" (2016: 257) şeklinde değerlendirir. Hasan Bedreddin'in Leblanc'dan yaptığı Arsène Lupin çevirisi hem Batılı bir eser olması hem de dönemin popüler türü olan polisiyeye ait olması bakımından Ülken’in değerlendirmesine örnek oluşturur niteliktedir.

Hasan Bedreddin, Arsène Lupin, Gentleman Cambrioleur'ü Arsen Lüpen’in Sergüzeştleri adıyla çevirir. Kaynak metinde Arsène Lupin’in birden fazla öyküsü, macerası anlatıldığı için çevirmenin bu başlı̆̆ı seçmiş olabileceği düşünülebilir.

İncelenen erek metinde iki kapak bulunmaktadır. Söz konusu kapaklar dış kapak ve iç kapak olarak adlandırılacaktır. Dış kapakta eserin, Haftalık Mecmua Neşriyatı'nın yayımladığı ikinci kitap olduğu bilgisi yer alır (bkz. Ek 12). Eserin kaynak dildeki adı kapakta bulunmaz, erek dildeki adı ise dış kapakta yazar. Hasan Bedreddin eserin "nâkili” şeklinde geçer; ancak önceki çevirilerde olduğu gibi bu çeviride de kaynak eser yazarının adı okurla paylaşılmaz. Eserin, 1926 yılında İstanbul'da, Vatan Matbaası'nda basıldı ̆̆ı, kapakta sunulan diğer bir bilgidir. Bu bilgilerin dışında kitabın fiyatı ve abonelik ücretinin ne kadar olacağı ayrıntılı bir şekilde belirtilir (bkz. Ek 12).

Erek metinde dış kapakta ve iç kapakta tanıtım yazısı olarak değerlendirilebilecek iki metin mevcuttur. Yayınevi tarafından kaleme alınan, dış kapaktaki ön sözde Arsène Lupin’in maceralarından övgüyle söz

\footnotetext{
Adres $\mid$ Address 
A descriptive study on the Ottoman Turkish (re)translations of Arsène Lupin, Gentleman Cambrioleur / G. Güler; A. B. Karadağ (pp. 654-682)

edilir. Erek kültürde eserin birinci cildine gösterilen rağbetten bahsedilir. Yayınevinin, gösterdikleri ilgi için okura teşekkür ettiği görülmektedir. Bu bilgi, çevirisi yapılan eserin ve yazarının erek kültürde tanınmış ve rağbet görmüş olmasının sonraki eserlerin seçiminde önemli bir etki yaratacağı şeklinde yorumlanabilir. Kapakta ve ön sözde bu durumdan bahsedilmesi, yayınevinin bir yandan eserin reklamını yapma, bir yandan da erek okurda yine aynı ilgiyi uyandırma çabası şeklinde değerlendirilebilir. Haftalı Мecmua dergisinin pazartesi ve perşembe günleri okurlarına birer baskı roman sunduğu ve her roman sona erdikçe yeni bir romana başlandığı ifade edilir. Ayrıca abonelik ücreti hakkında okura bilgi verilir. Yıllık abonelikte indirim yapılacağı bilgisi de okurla paylaşılır:

Haftalk Mecmua roman neşriyatının ikinci cildini teşkil eden “Arsen Lüpen”in baş döndüren ve akıl durduran merak-âver sergüzeştlerine başlarken muhterem karilerinin gösterdiği emsalsiz rağbet ve teveccühe arz-ı şükrânı vazife addeder.

Haftalı Mecmua'nın roman neşriyatı şubesi, pazartesi ve perşembe günleri karilere birer forma roman takdim etmekte ve her roman hitam buldukça bir başka romana başlamaktadır. Roman neşriyâtının senelik abonesi (104) forma itibariyle (450), altı aylık (52) forma itibariyle (250) kuruştur. Haftalı Mecmua abonelerine yüzde on tenzilât yapılır. Beher formanın fiyatı 5 kuruştur (bkz. Ek 12).

İç kapakta ise, "Sevgili Karilerimize" başlıklı ve "Haftalık Mecmua" imzalı bir ön söz bulunmaktadır. Bu ön sözde yayınevi, Arsène Lupin adının dahi okuru esere çekme konusunda yeterli olduğunu dile getirir. Birçok dile çevirisinin yapılmasıyla eserin dünya çapında şöhrete sahip olduğu ve okur tarafından rağbet gördüğü vurgulanmaktadır. Eserin çok sayıda dile çevrilmiş olması, birçok ülkede beğenildiğine ve okunduğuna işaret etmektedir. Ayrıca eserin çevirilerinin yapılmasının yanı sıra sinemaya uyarlanması da gördüğü ilgiyi ortaya koymaktadır. Eserin sinemaya uyarlandığı bilgisinin okura sunulması yayınevinin eser seçimini destekleyen bir unsur olarak düşünülebilir:

\section{Sevgili karilerimize}

“Arsen Lüpen’in Sergüzeştleri”!.. Bu kitabın sizi ne kadar eğlendireceğini, size ne kadar heyecanlı demler yaşatacağını başlı başına bu unvan şerh etmeye kâfidir. "Arsen Lüpen’in Sergüzeştleri” bütün dünyanın lisanlarına nakledilmiştir. Bütün dünyanın sinemalarına alınmıştır. Mütemadiyen binlerce sinemada gösteriliyor! (bkz. Ek 13).

Yayınevi ön sözün devamında, Arsène Lupin’in diğer ülkelerdeki emsallerine nazaran daha zeki, cesur ve azimli olduğunu vurgular. O güne kadar yapılan Arsène Lupin çevirileri hakkında bir değerlendirme yapar ve önceki çevirileri "eksik", "dağınık" ve "gerçek Arsène Lupin öykülerini anlatmaktan uzak" olmaları yönünden eleştirir. Buna karşılık kendi çevirilerinin, gerçek Arsène Lupin'in kim olduğunu göstereceği iddiasında bulunur. Söz konusu düşünceler şu şekilde aktarılmaktadır:

Avrupa ve Amerika'nın en namdar hafiyelerini âciz bırakan, zekâsı deha derecesine varan, azminin cüretkârlığının emsali bulunmayan bu "harika"nın vakıa bazı maceraları bizde gazetelerde, ötede beride darmadağınık bir hâlde intişar etmişti. Fakat o kadarı onun bütün kudretini, kuvvetini maharetini gösterebilmekten çok uzaktı. Onun için biz o türlülerine iltifat etmeyerek, bu birinci kitapta hakiki Arsen Lüpen'in ne olduğunu anlattıktan sonra, en meraklı en mahirü’l-'ukul vakalarından henüz işitilmemiş, lisanımıza nakledilmemiş olanlarını muhterem karilerimize takdim edeceğiz. Haftalık Mecmua (bkz. Ek 13).

Yayınevinin, Arsène Lupin öykülerinden "henüz işitilmemiş, lisanımıza nakledilmemiş olanlarını muhterem karilerimize takdim edeceğiz" ifadesinden, gelecek sayıyla ilgili bir planlama yaptığı, daha önce Türkçeye çevrilmemiş öykülerin çevirisini yapmayı amaçladığı ve bu düşüncesini okurla paylaştı̆̆ı anlaşılabilir. Ayrıca yayınevinin söz konusu ifadeyle kendinden önce yapılan Arsène Lupin çevirilerinden habersiz olması veya o çevirileri görmezden gelmesi ihtimallerini de göz ardı etmemek gerekir. 
Hasan Bedreddin’in, kaynak metinde yer alan öykülerin tamamının çevirisini yaptığı görülmektedir (bkz. Tablo 5).

Tablo 5

\begin{tabular}{|c|c|c|}
\hline & $\begin{array}{l}\text { Maurice Leblanc, } 1907 \\
\text { Arsène Lupin, Gentleman Cambrioleur }\end{array}$ & $\begin{array}{l}\text { Hasan Bedreddin, } 1926 \\
\text { Arsen Lüpen'ïn Sergüzeştleri }\end{array}$ \\
\hline 1. & "L'arrestation d'Arsène Lupin" (4-24) & “Arsen Lüpen’in Tevkifi” (3-18) \\
\hline 2. & “Arsène Lupin en prison" (25-54) & “Arsen Lüpen Hapishanede” (18-38) \\
\hline 3. & "L'évasion d'Arsène Lupin" (55-84) & "Arsen Lüpen’in Hapishaneden Firarı" (38-61) \\
\hline 4. & "Le mystérieux voyageur" (85-108) & "Esrarengiz Yolcu" (62-78) \\
\hline 5. & "Le Collier de la Reine" (109-133) & "Kraliçenin Gerdanlığı" (79-95) \\
\hline 6. & "Le sept de cœur" (134-187) & "Kupa Yedilisi” (96-128) \\
\hline 7. & "Le coffre-fort de Madame Imbert" (188-204) & “Madam İmber’in Kasası" (129-140) \\
\hline 8. & "La perle noire" $(205-225)$ & "Siyah İnci” (140-154) \\
\hline 9. & “Herlock Sholmès arrive trop tard” (226-263) & "Herlok Şolmz Geç Kaldı" (155-176) \\
\hline
\end{tabular}

Makalenin bir sonraki bölümünde, kaynak metindeki dokuz öyküden birincisi olan "L'arrestation d'Arsène Lupin”in ele alınan erek metinlerde nasıl öykülendiği üzerine karşlaştırmalı bir inceleme yapılacaktır.

\section{3. "L'arrestation d'Arsène Lupin”in Osmanlı Türkçesinde nasıl öykülendiği üzerine genel gözlemler}

"L'arrestation d'Arsène Lupin" adlı öykünün makalede ele alınan beş erek metinden dördünde çevirisinin yapıldığı görülmektedir. Söz konusu çeviriler sırasıyla Fazlı Necip, Süleyman Tevfik, Mustafa Remzi ve Hasan Bedreddin'e aittir. Bu bölümde ilk olarak "L'arrestation d'Arsène Lupin"in kaynak metindeki yeri ve konusuna değinilecek, daha sonra ise dört farklı erek metin öykü ana temasının kurgulanması bağlamında ayrı ayrı incelenecektir.

"L'arrestation d'Arsène Lupin" adlı öyküde "Provans" adlı bir transatlantik gemisinde Fransa'dan Amerika'ya seyahat eden yolcuların başından geçen olaylar anlatılır. Arsène Lupin'in gemide olduğu telgrafla yolculara bildirilir. Ancak Arsène Lupin hakkında bilgi verildiği sırada elektrik kesilir ve telgraf yarıda kalır. Sadece Arsène Lupin'in yalnız seyahat ettiği, "R" harfi ile başlayan bir ad kullandığı, kumral saçlı olduğu ve sağ kolunda bir yara bulunduğu iletilebilir.

Arsène Lupin, gemide kendisini Monsieur d'Andrésy olarak tanıtır, diğer yolculardan biri olan Miss Nelly ile yakın bir dostluk kurmaya çalışır ve gerçek kimliğini gizleyerek Arsène Lupin’in kim olabileceği konusunda Miss Nelly ile beraber fikir yürütmeye başlar. Telgrafta söylenenlerden hareketle tarif edilen özelliklere sahip kişiler arasında eleme yapmaya başlarlar. Monsieur Rozaine adlı kişinin belirtilen özellikleri taşıdığını düşünürler. Tam o sırada Miss Nelly’nin yakın arkadaşı Lady Jerland gelir ve mücevherlerinin çalınmış olduğunu haber verir. Bu hırsızlık olayı da yolcuların gözünde Arsène Lupin’in gemideki varlığını bir kez daha kanıtlar. Bunun üzerine Monsieur Rozaine üzerindeki şüpheler daha da artar ve herkes onun Arsène Lupin olduğunu düşünür. Bu olayın akabinde Monsieur Rozaine tutuklanır ancak Bordeaux'lu bir iş adamının oğlu olduğu ve kimlik belgelerinde de eksik bulunmadığı anlaşılınca serbest bırakılır. 

(pp. 654-682)

Yolcular Arsène Lupin'in kim olabileceğine dair tahmin yürütmeye devam ederken kaptanın saatinin çalındığı duyulur. Ancak olayın ertesi günü kaptanın saati ikinci kaptanın yakalıkları arasından çıkar. Başka bir sabah ise Monsieur Rozaine elleri bağlı ve üzerine bir kart iliştirilmiş vaziyette bulunur. Karttaki el yazısından Monsieur Rozaine’in kesin olarak Arsène Lupin olmadığı anlaşılır.

Yolculuğun sonuna doğru Amerika kıyları görünmeye başlar ve gemi kıyıya yaklaşır. Arsène Lupin’in ezelî düşmanı polis şefi Monsieur Ganimard'ın rıhtımda ekibiyle birlikte beklediği görülür. Arsène Lupin'in yakalanmama ihtimali yoktur. Tüm yolcular sırasıyla gemiden inmeye başlar ancak Ganimard inen hiçbir yolcu için istifini bozmaz. Sura Monsieur d'Andrésy ve Miss Nelly'ye geldiğinde ise onlara yaklaşır ve Monsieur d'Andrésy'den kimlik belgelerini ister. Arsène Lupin'in artık yapacak hiçbir şeyi kalmamıştır. Biraz dirense de teslim olmaya mecbur kalır. Yaşananları uzaktan izleyen Miss Nelly ise Arsène Lupin'in kendisine emanet ettiği, içinde Lady Jerland'ın mücevherlerinin bulunduğu fotoğraf makinesini elinden düşürüyormuş gibi yaparak denize atar ve yavaşça oradan uzaklaşır.

Öykünün sonunda Arsène Lupin’in anlatıcıyla olan arkadaşlıkları anlatılır. Arsène Lupin’in bir kış gecesi anlatıcıya geldiği ve başından geçen olayları kendisine anlattığı dile getirilir. Arsène Lupin tüm sırlarını, maceralarını, nasıl kılık değiştirdiğini anlatıcıya aktarır. Anlatıcının, Arsène Lupin’in kendisine samimiyetle anlattığı olayları dostluklarına güvenerek okurla paylaşacağını söylemesiyle öykü son bulur.

"L'arrestation d'Arsène Lupin" adlı öykünün dört erek metni incelendiğinde çeviri sürecinde çevirmenlerin farklı kararlar aldığı görülmektedir. İncelenen erek metinlerdeki bazı bölümlerde kaynak metinden parçalar çıkarılmış, bazı bölümlerde ise kaynak metne eklemeler yapılmıştır. Makalenin devamında söz konusu müdahaleler örneklendirilerek ele alınacaktır.

\section{1. "Arsen Lüpen"}

“L'arrestation d'Arsène Lupin” adlı öykü Fazlı Necip tarafından “Arsen Lüpen” adıyla çevrilmiştir. Erek metin "Provans" adlı bir transatlantik gemisindeki yolculukla başlar. Fransa'dan Amerika'ya gitmekte olan yolcuların başından geçen olaylar anlatılır. Arsène Lupin’in gemide olduğu bilgisinin telgrafla bildirilmesi üzerine tüm yolcular büyük bir endişeye kapılır. Yolculuk boyunca bazı hırsızlık olayları yaşanır ve Arsène Lupin’in kim olabileceği konusunda fikir yürütülür. Nihayet gemi Amerika kıyllarına yanaştı̆̆ında, ezelî rakibi polis şefi Monsieur Ganimard gemiden inen yolcular arasından Arsène Lupin’i bulur ve tutuklar. Öykü Arsène Lupin’in hapse atılmasıly son bulur.

Fazlı Necip’in kaynak metne yer yer eklemeler yaptığı, yer yer kaynak metinden bölümler çıkardığı görülmektedir. Bu konuyla ilişkilendirilebilecek örneklere aşağıda yer verilmiştir.

Kaynak metinde Arsène Lupin bin bir kılığa giren, kendisini birçok farklı meslek grubunda çalışıyormuş gibi gösteren biri olarak tanıtılmaktadır. Arsène Lupin her macerasında farklı bir kimliğe bürünür, hem mesleğini hem de fiziki görünüşünü değiştirir. Bu sayede bütün maceralarında yakalanmadan kurtulmayı başarır. Arsène Lupin'in girdiği kılıklardan bahsedilirken sayılan meslekler şu şekildedir:

KM: 
Arsène Lupin, l'homme aux mille déguisements: tour à tour chauffeur, ténor, bookmaker, fils de famille, adolescent, vieillard, commis-voyageur marseillais, médecin russe, torero espagnol!"12 (Leblanc, 1907: 6).

Birinci erek metinde Fazlı Necip Arsène Lupin’i tanıtırken kaynak metinde geçenlerden farklı meslekleri tercih eder. Bu anlamda çevirmenin, meslek grupları konusunda değişiklikler ve eklemeler yaptığı görülmektedir. Örneğin, kaynak metindeki “torero espagnol”un (İspanyol boğa güreşçisi) "İspanyalı tiyatrocu” şeklinde çevrilmesi tercih edilmiş, bunun yanı sıra kaynak metinde yer almayan "İtalyan şairi”, "fabrika seyahat memuru”, "Amerikalı milyoner" ve "İngiliz Lordu” gibi ifadeler metne eklenmiştir:

\section{EM 1:}

Bazen genç, bazen ihtiyar, bazen İtalyan şairi, bazı kere fabrika seyahat memuru, bazı kere Rusyalı bir doktor yahut Íspanyah bir tiyatrocu, bazı defa Amerikal milyoner yahut Ingiliz Lordu hâl ve kıyafetinde fevkalade mahirane sanatlara azim yekûnlar dolandırmaya muvaffak olduğu görülür (Leblanc (çev. Fazlı Necip), 1325 [1909]: 8).

Kaynak metinde telgraftaki bilgilerden hareketle gemide bulunan yolcular arasında Arsène Lupin’in kim olabileceği konusunda fikir yürütülmektedir. Hemen her yolcu grubu kendi arasında, kimlerin bahsedilen özelliklere sahip olduğu üzerine konuşur ve Arsène Lupin’i bulmaya çalışır. Bu konuşmalardan birinde telgrafta da belirtildiği gibi Arsène Lupin’in kumral olduğu söylenmektedir:

KM:

- C'est que vous oubliez les éléments que nous avons pour le résoudre.

- Quels éléments?

- 1. Lupin se fait appeler monsieur R...

- Signalement un peu vague.

-2 . Il voyage seul.

- Si cette particularité vous suffit.

- 3. Il est blond.

- Et alors?

- Alors nous n'avons plus qu'à consulter la liste des passagers et à procéder par élimination (Leblanc, 1907: 8).

Kaynak metinde yer alan bölümlerde Arsène Lupin "blond" (kumral) olarak tanıtılır. Erek metinde Fazlı Necip bu fiziksel görünüm bağlamında bir değişikliğe gitmeyi tercih eder ve kahramanı "mavi gözlü” olarak tarif eder:

EM 1:

Ahvali, etrafimızda bulunanları tetkik ve ta'mik ederek bir netice istihsaline muvaffak olamaz mıyız? Muamma hallolunamayacak kadar karışık değildir. Aradı̆̆ımız meçhulü bulmak için elimizde birçok malumatlar, ipuçları var. Evvela Arsen Lüpen vapurda taşıdığı nam-ı müstearın birinci harfi [R] olduğunu biliyoruz. Saniyen Arsen Lüpen'in seyahat refiki yoktur. Salisen Arsen Lüpen mai gözlü bir delikanlıdır. Şimdi birinci sınıf yolcularının esami defterini bir gözden geçirerek tetkik edersek aradığımızı bulmak güç bir iş addolunabilir mi? (Leblanc (çev. Fazlı Necip), 1325 [1909]: 10).

Kaynak metin Arsène Lupin'in yakalanmasının ardından anlatıcının Arsène Lupin ile tanışmasından bahsetmesiyle son bulmaktadır. Anlatıcı, Arsène Lupin'in aslında kim olduğunu, nasıl kllık

$12 \quad$ Kaynak metin ve erek metinlerden alıntılanan örneklerdeki italik vurgular tarafımıza aittir. 
değiştirdiğini, kendisini nasıl gizlediğini ve nasıl dost olduklarını anlatır. Ayrıca, Arsène Lupin’in kendisine anlattığı maceralarını okurla paylaşacağını dile getirir:

KM:

C'était ainsi qu'un soir d'hiver, Arsène Lupin me raconta l'histoire de son arrestation. Le hasard d'incidents dont j'écrirai quelque jour le récit avait noué entre nous des liens... dirais-je d'amitié? Oui, j'ose croire qu'Arsène Lupin m'honore de quelque amitié, et que c'est par amitié qu'il arrive parfois chez moi à l'improviste, apportant, dans le silence de mon cabinet de travail, sa gaieté juvénile, le rayonnement de sa vie ardente, sa belle humeur d'homme pour qui la destinée n’a que faveurs et sourires (Leblanc, 1907: 23).

Kaynak metinde yer alan yukarıdaki bölümün erek metinden tamamen çıkarıldığı görülmektedir. Arsène Lupin'in gizeminin okurla paylaşıldığı bu bölümü çevirmemeyi tercih eden Fazlı Necip’in erek kültür okuru için bu gizemi saklı tutmak istediği düşünülebilir. Söz konusu parça dışında çevirmenin kaynak metinden eksilttiği başka bir bölüm bulunmamaktadır.

\section{2. “Arsen Lüpen'in Tevkifi”}

Süleyman Tevfik "L'arrestation d'Arsène Lupin" adlı öyküyü "Arsen Lüpen'in Tevkifi" adıyla çevirmiştir. Erek metinde yer alan olaylar şu şekilde özetlenebilir: Yolcular "Provans" adlı bir transatlantik gemisinde Fransa'dan Amerika'ya seyahat eder. Yolculuk boyunca, gemidekiler arasından kimin Arsène Lupin olabileceği sorgulanır ancak bir sonuca varılamaz. Yolculuk bitip Amerika kıylarına varıldığında polis şefi Monsieur Ganimard, Arsène Lupin’i tutuklar. Erek metnin son bölümünde anlatıcı Arsène Lupin ile olan dostluğundan bahseder ve Arsène Lupin'in maceralarını aktarır:

KM:

C'était ainsi qu'un soir d'hiver, Arsène Lupin me raconta l'histoire de son arrestation. Le hasard d'incidents dont j'écrirai quelque jour le récit avait noué entre nous des liens... dirais-je d'amitié? Oui, j'ose croire qu'Arsène Lupin m'honore de quelque amitié, et que c'est par amitié qu'il arrive parfois chez moi à l'improviste, apportant, dans le silence de mon cabinet de travail, sa gaieté juvénile, le rayonnement de sa vie ardente, sa belle humeur d'homme pour qui la destinée n’a que faveurs et sourires (Leblanc, 1907: 23).

İncelenen birinci erek metnin aksine ikinci erek metinde Arsène Lupin'in anlatıcı ile kaynak metinde yukarıdaki şekilde aktarılan ilişkisine yer verilir. Süleyman Tevfik'in bu bölümü çevirmeyi tercih ettiği görülmektedir:

EM 2:

Bir kış gecesi Arsen Lüpen kendinin nasıl tevkif olunduğunu vechle bana hikâye etti. Zirde yazacağım bir tesadüf onunla benim aramda bir nevi rabita hasıl eylemişti. Buna dostluk diyebiliyor muyum? Evet. Zannedebiliyorum ki Arsen Lüpen beni dostluğu ile müşerref kıllyor. [...] İşte onun bana hikâye eylediği vechle bazı efal ve harekâtını tarif ve hikâye etmeye çalışıyorum. Çünkü o bazı kış geceleri gelip hücre-i iştigalimde bana bunları anlatmak lütfunda bulunur (Leblanc (çev. Süleyman Tevfik), 1333 [1917]: 23-24).

Bununla birlikte Süleyman Tevfik'in kaynak metindeki bazı bölümleri çevirmediği görülmektedir. Örneğin kaynak metindeki maceralarından birinde Arsène Lupin Baron de Schormann'ın evine gider ancak evdeki eşyaların "authentique" (orijinal) olmaması sebebiyle hiçbir eşyayı almaz ve bir kartvizit yazarak oradan ayrilır:

KM: e-posta: editor@rumelide.com
Address

Kırklareli University, Faculty of Arts and Sciences, Department of Turkish Language and Literature, Kayalı Campus-Kırklareli/TURKEY e-mail: editor@rumelide.com 
Arsène Lupin, le fantaisiste gentleman qui n'opère que dans les châteaux et les salons, et qui, une nuit, où il avait pénétré chez le baron Schormann, en était parti les mains vides et avait laissé sa carte, ornée de cette formule: "Arsène Lupin, gentleman-cambrioleur, reviendra quand les meubles seront authentiques” (Leblanc, 1907: 6).

Kaynak metinde yer alan yukarıdaki bölümün çeviri metinde yer almadığı görülmektedir. Süleyman Tevfik’in bu bölümü önemsiz görerek çevirmediği iddia edilebilir. Ayrıca, kaynak metinde Arsène Lupin’in girdiği kılıklar "chauffeur" (şoför), "ténor” (tenor), "bookmaker” (bahis yazmanı/kitapçı), "fils de famille" (iyi aile çocuğu), "adolescent" (yeniyetme), "vieillard” (yaşlı), "commis-voyageur marseillais" (Marsilyalı gezgin satıc1), "médecin russe" (Rus doktor), "torero espagnol” (İspanyol boğa güreşçisi) şeklinde sıralanırken söz konusu bölüm erek metinde şu şekilde yer almaktadır:

EM 2:

Bin türlü tebdil-i kıyafet eden, en büyük salonlara girip çıkan, kâh şoför, aktör, kitapçı, mücellit, hanedan evlad, genç, ihtiyar, seyyar ticarathane memuru, tabip ve pehlivan velhasil her saatte bir şekil ve suret alan "Arsen Lüpen"in bizim vapurda vapurun da en dar köșesi olan birinci mevkide aramızda, her dakika salonda, yemekte, sigara salonunda bulunması ihtimali cümlemize ne kadar büyük bir telaşi olduğunu düşünmek kifayet eder (Leblanc (çev. Süleyman Tevfik), 1333 [1917]: 5).

Dolayısıyla çevirmenin kaynak metinde Arsène Lupin ile ilgili sıralanan mesleklerde bir değişikliğe gittiği görülmektedir. Süleyman Tevfik "ténor" (tenor) sözcügüne karşllı "aktör” sözcüğünü, "torero espagnol” (İspanyol boğa güreşçisi) sözcüğüne karşllı "pehlivan” sözcüğünü kullanırken "commisvoyageur marseillais" (Marsilyalı gezgin satıcı) sözcüğüne karşllı sadece "seyyar ticarethane memuru", "médecin russe" (Rus doktor) sözcügüne karşllı sadece "tabip” sözcügünü kullanmayı tercih ederek kaynak metindeki "Marsilyalı" ve "Rus" sıfatlarına çevirisinde yer vermemiştir.

\section{3. "Tevkif"}

Mustafa Remzi, "L’arrestation d’Arsène Lupin” adlı öyküyü "Tevkif" adıyla çevirmiştir. Erek metnin Arsène Lupin, Gentleman Cambrioleur’ün ilk üç öyküsünü kapsadığı görülmektedir.

"Tevkif" adlı erek metinde "Provans" adlı bir transatlantik gemisindeki yolculuk yer alır. Bu gemi, içinde Arsène Lupin'in de bulunduğu yolcu grubunu Marsilya'ya taşır. Arsène Lupin’in gemide olduğu, bir telgrafla yolculara bildirilir. Ancak Arsène Lupin'in eşkâlinin bildirildiği sirada elektrik kesilir ve telgraf yarıda kalır. Bu durum da tüm yolcuları endişeye sevk eder. Yolculuk sırasında gemide bulunan polis şefi Monsieur Ganimard, Arsène Lupin’i yakalar ve onu bir odaya kapatmaya karar verir. Bu sırada Arsène Lupin el çabukluğuyla Ganimard'ın elinden kurtulmayı başarır. Daha sonra Arsène Lupin, Ganimard'ın ellerini ve kollarını bağlar ve onun kılığına girerek yolcuların arasına karışır. Ancak Arsène Lupin’in Ganimard olmadığı anlaşılır ve gerçek Ganimard kapalı kaldığı odadan kurtarılır. Yolculuğun sonunda Arsène Lupin tutuklanır ve hapishaneye götürülür. Erek metin Arsène Lupin'in bir gece hapishaneden kaçması ve Paris'e gitmesiyle son bulur.

Mustafa Remzi'nin Arsène Lupin, Gentleman Cambrioleur'de yer alan "L'arrestation d'Arsène Lupin" adlı birinci öyküyü, "Arsène Lupin en prison" adlı ikinci öyküyü ve "L'évasion d'Arsène Lupin” adlı üçüncü öyküyü "Tevkif” adlı erek metninde birleştirdiği ve metnine bahsi geçen üç öyküde de yer almayan farklı bir son eklediği görülmektedir. Bu bilgilere dayanılarak çevirmenin metnini kaynak metne göre oldukça farklı bir şekilde sunmayı tercih ettiği söylenebilir. 

(pp. 654-682)

Ayrıca, Mustafa Remzi’nin kaynak öyküde yer alan bazı bölümlere birtakım müdahalelerinin olduğu görülmektedir. Çevirmen erek metne kaynak metinde olmayan bazı bölümler eklemeyi, kaynak metinde yer alan bazı bölümleri ise erek metinden tamamen çlkarmayı uygun görmüştür. Bunlarla ilişkilendirilebilecek örnekler aşağıda sunulmuş̧tur.

Kaynak metinde Baron de Schormann'ın evine giden Arsène Lupin’in evdeki eşyaları çalmamasının sebebi eşyaların "authentique" (orijinal) olmaması olarak gösterilmektedir (Leblanc, 1907: 6). Çevirmen bu noktada bir değişikliğe giderek Arsène Lupin’in Baron de Schormann'ın evinden eli boş çıkmasının sebebini evde eşya olmaması olarak gösterir:

EM 3:

Mesela bir gün Baron dö Şarmet'in evine girmiş, mobilya vesaire namına hiçbir şey bulamadığı için kartonun üzerine şu cümleleri yazarak bırakıp gitmiştir:

\section{Arsen Lüpen}

Centilmen hirsiz

Mobilya mevcut olduğu zaman tekrar gelecek (Leblanc (çev. Mustafa Remzi), 1341 [1925]: 5-6).

Kaynak metinde Arsène Lupin "chauffeur", "ténor", "bookmaker", "fils de famille", "adolescent", "vieillard", "commis-voyageur marseillais", "médecin russe”, "torero espagnol” şeklinde tanitılırken Mustafa Remzi’nin erek metinde farklı meslekler saydığı görülmektedir:

EM 3:

Arsen Lüpen; el çabukluğuyla bir kıyafet değiştirir: Şoför, muganni, asilzade çok genç adam, ihtiyar, seyyar komisyoncu, doktor vesaire... Arsen Lüpen şimdi sirkatinin hududunu bir transatlantik vapurunda tahdid etmişti (Leblanc (çev. Mustafa Remzi), 1341 [1925]: 6).

Kaynak metinde Miss Nelly gemideki yolculardan biridir. Arsène Lupin, yolculuk boyunca Monsieur d'Andrésy adı altında ona kur yapar ve yakınlaşmaya çalışır. Miss Nelly hem güzelliğiyle hem de zenginliğiyle gösterişli ve alımlı bir kadındır. Arkadaşı Lady Jerland ile birlikte seyahat etmektedir. Arsène Lupin'in gemide olmasından en çok kaygı duyanlardan biridir. Arsène Lupin de bu durumu fırsata çevirerek sürekli Miss Nelly'nin yakınında durmaktadır. Kaynak metinde Miss Nelly'nin gözlerinin siyah olduğu belirtilmektedir:

\section{KM:}

Dès la première heure, j'avais posé ma candidature de flirt. Mais dans l'intimité rapide du voyage, tout de suite son charme m'avait troublé, et je me sentais un peu trop ému pour un flirt quand ses grands yeux noirs rencontraient les miens. Cependant, elle accueillait mes hommages avec une certaine faveur. Elle daignait rire de mes bons mots et s'intéresser à mes anectodes. Une vague sympathie semblait répondre à l'empressement que je lui témoignais (Leblanc, 1907: 7).

Miss Nelly'in kaynak metinde "noir" (siyah) olarak belirtilen göz rengini çevirmenin erek metinde bir değişikliğe giderek "yeşil" şeklinde çevirmeyi uygun gördüğü görülmektedir. Bu konudaki örneklerden biri aşağıda sunulmuştur:

EM 3:

Biraz sonra Ganimar Mis Nelli’yi çağırdı. Mis bulunduğu yerden koşa koşa geldi. Ganimar beni göstererek:

- Takdim ederim Mösyö Arsen Lüpen dedi.

Ve o zaman Mis Nelli’nin ağzı açık kaldı: 


\author{
- Ne diyorsunuz Mösyö Ganimar? \\ - Size diyorum ki: Andrezi namıyla aramızda sokulan bu adam meşhur hırsız Arsen Lüpen'dir. \\ Gözlerimi Mis Nelli’nin yeşil gözlerine diktim o da bana derin derin baktı: \\ “Elan gözlerimin sihrinden kurtulamamıştı” (Leblanc (çev. Mustafa Remzi), 1341 [1925]: 22).
}

Erek metin-kaynak metin karşılaştırmasında gözlemlenen farklılıklar çerçevesinde ele alınabilecek örneklerden bir diğeri olarak Arsène Lupin'in yakalanması verilebilir. Kaynak metinde Arsène Lupin gemi yolculuğunun sonunda Amerika kıyılarına varıldığında tutuklanır. Polis şefi Monsieur Ganimard diğer polislerle birlikte rihtımda beklemektedir. Erek metinde ise Monsieur Ganimard da gemideki yolcular arasında bulunur ve Arsène Lupin gemide yakalanır:

EM 3:

Evet ben Arsen Lüpen'im... Ledi Jerland’ın mücevherlerini çalan, kaptanın saatini ikinci kaptanın mendilinin arasına koyan ve bütün dünyaya şöhret salan Arsen Lüpen benim...

- Hah... Yakaladık... dedi.

Ve sonra:

- Kanunen sizi tevkif ediyorum dedi.

O zaman ben kendime geldim. Fakat hiç mümanaat göstermedim. Derhâl itaat ettim.

Cebinden ince bir kelepçe çıardı ve bileğime taktı. Ve sonra beni güvertenin tenha bir köșesine çekti (Leblanc (çev. Mustafa Remzi), 1341 [1925]: 21-22).

Kaynak metin Arsène Lupin’in rıhtımda yakalanması ve anlatıcının Arsène Lupin ile ilişkisini anlatmasıyla son bulur. Arsène Lupin'in hapishanede yaşadıkları ise Arsène Lupin, Gentleman Cambrioleur'ün ikinci öyküsü olan “Arsène Lupin en prison”da anlatılır. Mustafa Remzi metninde bu bölümde de bir değişikliğe gitmeyi tercih etmiştir. Erek metinde Arsène Lupin gemide yakalandıktan sonra, yolculuğun sonunda gemi Marsilya’ya vardığında hapishaneye götürülür ve ikinci gecesinde hapishaneden kaçar:

EM 3:

Sonra Marsilya'ya geldiğimiz zaman çıktık ve doğru tevkifhaneye girdim. Tevkifhanede ilk geceyi biraz acemilikle geçirdim. Fakat ikinci gece:

$[\ldots]$

İskemlemden doğruldum pencereden şöyle aşağı göz gezdirdim. Dört beş irtifada bir yerdi.

Herhalde inerdim. Fakat büyük avludan geçtikten sonra kapıdan nasıl çıkacaktım. Bunu düşünmekle beraber derhal pencereden aşağıya atladım. Ve iki ayağımın uçlarına düştüm. Ağır ağır yürüyerek avluyu bitirdim ve büyük kapıya geldim. Polis kulübesine benzeyen odanın tepesinde yanan elektriğin altında nöbetçinin mışıl mışıl uyuduğunu gördüm. Kapıyı açtım. Müsterih bir kalple yavaş yavaş tevkifhaneden uzaklaştım (Leblanc (çev. Mustafa Remzi), 1341 [1925]: 29-30).

Mustafa Remzi'nin çeviri metninde yer alan son bölüm, kaynak metindekinden oldukça farklıdır. Son bölümde yaptı̆̆̆ değişiklik, çevirmenin metin üzerindeki en dikkat çekici müdahalelerinden biri olarak yorumlanabilir. Kaynak metin Arsène Lupin'in anlatıcı ile olan ilişkisinin anlatılmasıyla biterken Mustafa Remzi, çevirisinde son bölüme bazı eklemeler yapmış, metni farklı bir sonla bitirmiştir. Erek metindeki son bölümün kaynak metindekinden farklılaşmasına bir örnek olarak aşağıdaki kısım gösterilebilir:

EM 3:

\footnotetext{
Adres Address 
A descriptive study on the Ottoman Turkish (re)translations of Arsène Lupin, Gentleman Cambrioleur / G. Güler; A. B. Karadağ (pp. 654-682)

Açık bir şapkacı dükkânından silindir bir şapka aldım ve gece yarısı treniyle Paris’e müteveccihen hareket ettim. İsterseniz size orada ne yapacağımı söyleyeyim:

Eski şapkamın içine sakladığım paralarla ayakkabımın kutu gibi topuğuna koyduğum mücevherleri orada kadınlarla yiyeceğim (Leblanc (çev. Mustafa Remzi), 1341 [1925]: 30).

Makalenin birinci bölümünde Üyepazarcı'nın görüşleri çerçevesinde vurgulanmış olduğu gibi Mustafa Remzi, eserlerinde okurun dikkatini çekmek için sık sık "kadın” sözcüğüne başvurma eğilimindedir. İncelenen eser özelinde de kaynak metinde olmamasına rağmen erek metnin sonuna eklenen yukarıdaki kısımda "Mücevherleri orada kadınlarla yiyeceğim" cümlesiyle çevirmenin "kadın" vurgulu bir yorumda bulunduğu görülebilir.

\section{4. "Arsen Lüpen'in Tevkifi”}

Hasan Bedreddin’in "Arsen Lüpen’in Tevkifi” başlıklı erek metni "L'arrestation d'Arsène Lupin”in ilk tam çevirisi olarak değerlendirilebilir. Genel olarak bakıldığında çevirmenin kaynak metnin bütünlüğünü koruma çabasında olduğu söylenebilir.

Erek metin Fransa'dan Amerika'ya olan gemi yolculuğu ile başlar. Gemide Arsène Lupin'in bulunması ve yolculuk sırasında yaptığı hırsızlıklar tüm yolcuları endişelendirir. Arsène Lupin gemideki yolculardan Miss Nelly ile dostluk kurmaya çalışır. Miss Nelly dâhil hemen hemen her yolcu Arsène Lupin’in kim olabileceği konusunda fikir yürütür. Dikkatler Monsieur Rozaine'in üzerinde yoğunlaşsa da onun Arsène Lupin olmadığı anlaşlır. Yolculuk bittiğinde, rıhtımda bekleyen Monsieur Ganimard Arsène Lupin’i tutuklar. Erek metin, anlatıcı ve Arsène Lupin arasındaki ilişkinin açıklanmasıyla biter.

Daha önceki erek metinlerde ya hiç çevrilmemiş ya da kaynak metinden uzaklaşlarak çevrilmiş olan, Arsène Lupin'in Baron de Schormann'ın evindeki hırsızlık bölümünün ilk kez Hasan Bedreddin'in çevirisinde kaynak metne koşut bir biçimde çevrildiği görülmektedir. Erek metinde Arsène Lupin’in eşyaları almamasının sebebi kaynak metinde geçtiği gibi yer almaktadır:

EM 4:

Öyle kibar bir hırsız ki sirkatlerini ancak şatolarda ve en yüksek salonlarda ika‘ ederdi... Bir gece Baron "Şorman” kartvizit bırakmıştı: "Arsen Lüpen, kibar hırsız, eşya böyle taklit değil, hakiki olacağı vakit tekrar gelecektir” (Leblanc (çev. Hasan Bedreddin), 1926: 4).

Kaynak metindeki meslekler ise Hasan Bedreddin’in çevirisinde şu şekilde yer almaktadır:

EM 4:

O, Arsen Lüpen ki binbir türlü heyete girer, sırasıyla şoför, aktör, tenor, komisyoncu, yarışçı, aile çocuğu, genç mürahik, ihtiyar, Marsiyal tacir, Rusyal doktor, İspanyah boğa pehlivan kıyafetlerinde arz-1 endam ederdi (Leblanc (çev. Hasan Bedreddin), 1926: 4).

\section{Sonuç gözlemleri}

$\mathrm{Bu}$ makalede polisiye roman türünde popüler bir örnek olan Arsène Lupin, Gentleman Cambrioleur'ün 1908-1928 yılları arasındaki (yeniden) çevirileri yan-metinsel ögeler ışı̆̆ında betimleyici bir çalışmayla ele alınmıştır. Erek metinlerde yer alan, çevirmen veya yayınevi tarafından kaleme alınmış ön söz, son söz ve eser kapakları incelendiğinde, eser seçimini belirleyen etkenlere dair bilgilerin sunulduğu görülmüştür. 
Arsène Lupin serisinin Türk edebiyat dizgesinde polisiye roman türünün doğuşuna ve gelişmesine kaynaklık etmek yoluyla önemli bir yere sahip olduğu söylenebilir. Bahsi geçen eserin ve çevirilerinin incelenmesinin özellikle II. Meşrutiyet sonrası dönemde, ülkemizde çeviri edebiyat pratiklerine dair ipuçları sunduğu düşünülmektedir.

Sonuç olarak, çok kısa bir zaman aralığında aynı eserin beş farklı çevirisinin yapılmış olması bahsi geçen dönemde Türk okurunun edebiyatımıza çeviri yoluyla giren polisiyeye ilgisinin bir göstergesi olarak yorumlanabilir. Ayrıca, yapılan Arsène Lupin çevirilerinin yerli Arsène Lupin örneklerinin üretilmesine kaynaklık ettiği iddia edilebilir. Bu bağlamda söz konusu (yeniden) çevirilerin Türk kültür ve edebiyat dizgesinde öncü bir role sahip olduğu ve bu öncü rolün Osmanlı çeviri anlayışı temelinde irdelenmesinin çeviri edebiyat tarihimize ışık tutacağı düşünülmektedir.

\section{Kaynakça}

Akbulut, A. N. (2011). Tanıklarla Çeviri ve Cortázar. İstanbul Üniversitesi Çeviribilim Dergisi, Cilt 2, Sayl 3.

Ali Seydi. (1330) [1911]. Resimli Kamus-ı Osmanî. İstanbul: Matbaa ve Kütüphane-i Cihan.

Altıntaş Balcı, A. (2005). Türklerin Sherlock Holmes'ü Amanvermez Avni. (Yayımlanmamış Yüksek Lisans Tezi). Bilkent Üniversitesi, Ekonomi ve Sosyal Bilimler Enstitüsü, Ankara.

Altıntaş, Ö. ve Karadă̆, A. B. (2019a). Polisiye Edebiyatta Ulusal Alegori Çevirisi: Amanvermez Avni'nin Serüvenleri. Trakya Üniversitesi Edebiyat Fakültesi Dergisi, Cilt 9, Sayı 17, 277-295.

Altıntaş, Ö. ve Karadağ, A. B. (2019b). İlk Türk Polisiye Serilerini Çeviribilim Bağlamında Yeniden Düşünmek. RumeliDE Dil ve Edebiyat Araştırmaları Dergisi, Sayı Ö5, 387-400.

Andı, F. (1993). Fennî Roman. Dergâh, Sayı 37, 11-18.

Baydere, M. ve Karadağ, A. B. (2019). Çalıkuşu'nun Öz-Çeviri Serüveni Üzerine Betimleyici Bir Çalışma. RumeliDE Dil ve Edebiyat Araştırmaları Dergisi, Sayı Ö5, 314-333.

Bensimon, P. (1990). Présentation. Palimpsestes, Cilt 13, Sayl 4, ix-xiii.

Berk Albachten, Ö. ve Tahir Gürçăglar, Ş. (Ed.) (2019a). Perspectives on Retranslation. Ideology, Paratexts, Methods. Londra ve New York: Routledge.

Berk Albachten, Ö. ve Tahir Gürçağlar, Ş. (Ed.) (2019b). Studies from a Retranslation Culture: The Turkish Context. Singapur: Springer.

Berman, A. (1990). La Retraduction comme Espace de Traduction. Palimpsestes, Cilt 13, Sayl 4, 1-7.

Birkan Baydan, E. (2015). Tanzimat Dönemi Çeviri Romanlarında "Yeniden Çeviri” Örnekleri. The Journal of Academic Social Science Studies, Cilt 39, Sayl 1, 173-187.

Bozkurt, E. (2014). 1908-1928 Yilları Arasında Bat Dillerinden Osmanh Türkçesine Çevrilen Romanlarda Mukaddime Geleneği. (Yayımlanmamış Doktora Tezi). Ylldız Teknik Üniversitesi, Sosyal Bilimler Enstitüsü, İstanbul.

Bozkurt, E. ve Karadă̆, A. B. (2012). Ön Sözleri Tanıklığında Bir Gazeteci, Romancı, Oyun Yazarı, Dergici, Sözlükbilimci, Dilbilimci, Ansiklopedist, Şârih ve Çevirmen: Şemseddin Sâmi. İstanbul Üniversitesi Dilbilim Dergisi, Cilt 1, Say1 27, 27-53.

Bozkurt, E. ve Karadağ, A. B. (2014). Türk Kültür ve Edebiyat Dizgesinde Çok Kimlikli Bir Mütercim: Süleyman Tevfik. RumeliDE Dil ve Edebiyat Araşttrmaları Dergisi, Sayı 38, 38-59.

Brownlie, S. (2006). Narrative Theory and Retranslation Theory. Across Languages and Cultures, Cilt 7, Sayl 2, 145-170.

Chesterman, A. (2000). A Casual Model for Translation Studies. Intercultural Faultlines. (Ed.) M. Olohan. Manchester: St. Jerome. 15-27. 
A descriptive study on the Ottoman Turkish (re)translations of Arsène Lupin, Gentleman Cambrioleur / G. Güler; A. B. Karadağ (pp. 654-682)

Couégnas, D. (2016). Naissance d'un Héros et d'un Ensemble Sériels: Arsène Lupin, GentlemanCambrioleur (1905-1907). Belphégor. Littérature Populaire et Culture Médiatique, Sayı 14, 113.

Çelenk, Z. (2005). Esrâr-ı Cinâyât'tan Çoksatarlığın Esrarlarına: Ülkemizde Yazarın ve Romanın Polisiye Macerası. Pasaj Edebiyat Eleştirisi Dergisi. Sayı 2. Eylül-Aralık. 159-182.

Demircioğlu, C. (2003). 19. Yüzyll Sonu Türk Edebiyatında "Tercüme" Kavramı. Journal of Turkish Studies (Türklük Bilgisi Araştırmalar). Günay Kut Armağanı, Cilt 27, Sayı 2, 13-31.

Demircioğlu, C. (2005). From Discourse to Practice: Rethinking “Translation" (Terceme) and Related Practices of Text Production in the Late Ottoman Literary Tradition. (Yayımlanmamış Doktora Tezi). Boğaziçi Üniversitesi, Sosyal Bilimler Enstitüsü, İstanbul.

Demircioğlu, C. (2008). Tuzaklar ve "Kapılar": Osmanlıda Çeviri Tarihini Araştırırken Nereden Başlamalı?. Çeviribilimde Yeni Ufuklar, Uluslararası Çeviri Sempozyumu. Ankara: Bizim Büro Basımevi Yayıncılık Dağıtım. 237-249.

Demircioğlu, C. (2009). Osmanlı Çeviri Tarihi Araştırmaları Açısından "Terceme" ve "Çeviri” Kavramlarını Yeniden Düşünmek. Journal of Turkish Studies (Türklük Bilgisi Araştırmaları). Cem Dilçin Armağını, Cilt 33, Sayı 1, 159-177.

Drake, D. (2009). Crime Fiction at the Time of the Exhibition: The Case of Sherlock Holmes and Arsène Lupin. Synergies Royaume-Uni et Irlande, Sayl 2, 105-117.

Erkul Yağcl, A. S. (2019). Tracing the History of the Novel as a Genre in Turkey (1908-1940). Comparative Critical Studies, Cilt 16, Sayı 2-3, 343-364.

Gambier, Y. (1994). La Retraduction, Retour et Détour. Meta, Cilt 39, Sayl 3, 413-417.

Gezer, H. (2006). Türk Edebiyatında Polisiye Roman ve Ahmet Ümit’in Polisiye Roman Kurgularl. (Yayımlanmamış Yüksek Lisans Tezi). Süleyman Demirel Üniversitesi, Sosyal Bilimler Enstitüsü, Isparta.

Gündüz, O. (2009). Geleneksel Anlatma Formlarından Çă̆daș Romana. Turkish Studies. International Periodical for the Languages, Literature and History of Turkish or Turkic, Cilt 4, Sayl 1, 763-798.

Güneş, A. Z. (2018). The Retranslation of The Time Regulation Institute: A Project of Respect or Prejudice?. (Ed.) S. Taş. Çeviribilimde Güncel Tartışmalardan Kavramsal Sorgulamalara. İstanbul: Hiperlink Yayınları. 379-411.

Karadağ, A. B. (2012). Çeviri Tarihimizde Fennî Romanlarla Bir Kültür Repertuarı Oluşturmak. İstanbul Üniversitesi Çeviribilim Dergisi, Cilt 2, Sayı 6, 45-73.

Karadă̆, A. B. (2014). Tanzimat'tan II. Meşrutiyet'e Çeviri Roman Hâllerine Ön Söz/Son Söz Tanıklıkları. Metnin Hâlleri: Osmanlıda Telif, Tercüme ve Şerh. (Ed.) H. Aynur, M. Çakır, H. Koncu, S. S. Kuru ve A. E. Özyıldırım. 94-145. İstanbul: Klasik Yayınları.

Karadağ, A. B. (2019). Türk Edebiyat ve Kültür Dizgesinin Konukseverliğinde Çeviri Roman Deneyimi. Doğu-Batı, Cilt 22, Sayı 88, 8-25.

Karadağ, A. B. ve Bozkurt, E. (2014). II. Meşrutiyet’ten Harf Devrimi'ne Kadar Osmanlıcaya Yapılan Roman Çevirilerinin Süreç Öncesi Normlar Bağlamında İrdelenmesi. Humanitas, Sayı 3, Bahar, $85-103$.

Koskinen, K. ve Paloposki, O. (2003). Retranslation in the Age of Digital Reproduction. Cadernos, Sayı $1,19-38$.

Koskinen, K. ve Paloposki, O. (2010). Retranslation. Handbook of Translation Studies. (Ed.) Y. Gambier ve L. Doorslaer. Amsterdam: John Benjamins. Cilt 1, 294-298.

Leblanc, M. (1907). Le Gentleman Cambrioleur. Paris: Editions Pierre Lafitte.

Leblanc, M. (1325) [1909]. Arsen Lüpen (Çev. Fazlı Necip). Selanik: Yeni Asır Matbaası.

Leblanc, M. (1325) [1909]. Sarik Arsen Lüpen (Çev. Osman Vefik). İstanbul: Dersaadet.

\footnotetext{
Adres $\mid$ Address 
Leblanc, M. (1333) [1917]. Arsen Lüpen Hem Kibar! Hem Hirsız!!! (Çev. Süleyman Tevfik). İstanbul: Kader Matbaası.

Leblanc, M. (1341) [1925]. Arsen Lüpen Hapishanede (Çev. Mustafa Remzi). İstanbul: Sühûlet Matbaası.

Leblanc, M. (1926). Arsen Lüpen’in Sergüzeştleri (Çev. Hasan Bedreddin). İstanbul: Vatan Matbaası.

Özege, M. S. (1971). Eski Harflerle Basılmış Türkçe Eserler Kataloğu. Cilt 1. İstanbul: Fatih Yayınevi Matbaası.

Özege, M. S. (1973). Eski Harflerle Basılmış Türkçe Eserler Kataloğu. Cilt 2. İstanbul: Fatih Yayınevi Matbaası.

Özege, M. S. (1975). Eski Harflerle Basılmış Türkçe Eserler Kataloğu. Cilt 3. İstanbul: Fatih Yayınevi Matbaası.

Özege, M. S. (1977). Eski Harflerle Basılmış Türkçe Eserler Kataloğu. Cilt 4. İstanbul: Fatih Yayınevi Matbaası.

Özege, M. S. (1979). Eski Harflerle Basılmış Türkçe Eserler Kataloğu. Cilt 5. İstanbul: Fatih Yayınevi Matbaasi.

Paker, S. (2014). Terceme, Te'lîf ve Özgünlük Meselesi. Metnin Hâlleri: Osmanl'da Telif, Tercüme ve Şerh. (Ed.) H. Aynur, M. Çakır, H. Koncu, S. S. Kuru ve A. E. Özyıldırım, 36-71. İstanbul: Klasik Yayınları.

Paloposki, O. ve Koskinen, K. (2004). Thousand and One Translations: Revisiting Retranslation. Claims, Changes and Challenges in Translation Studies. (Ed.) G. Hansen, K. Makmkjaer and D. Gile. Amsterdam: John Benjamins. 27-38.

Paloposki, O. ve Koskinen, K. (2010). Reprocessing Texts: The Fine Line between Retranslating and Revising. Across Languages and Cultures, Cilt 11, Sayl 1, 29-49.

Pym, A. (1998). Method in Translation History. Manchester: St. Jerome.

Susam-Sarajeva, S. (2003). Multiple-entry Visa to Travelling Theory: Retranslations of Literary and Cultural Theories. Target, Cilt 15, Sayı 1, 1-36.

Şahin, S. (2009). Nâhid Sâmi: Yirminci Asrın Kibar Hırsızı-Süleyman Sûdî ve E. Âli'nin Gece Kuşları Romanı Üzerine. Yeni Türk Edebiyatı Araştırmaları, 1. Ocak-Haziran, 179-188.

Şahin, S. (2011). Auratik Hırsızın Tarihsel Sermayesi-Cingöz Recai Serileri Üzerine Bir Çoklu Uyum Analizi Uygulaması. Folklor/Edebiyat, Cilt 17, Sayı 68, 9-30.

Şahin, S., Ardalı Büyükarman, D., Öztürk, B., Şahin A. ve Şahbenderoğlu, İ. (2011-2014). 1884-1928'de Türkiye'de Yayımlanmış Telif Polisiye Eserlerin Tarihi, TÜBİTAK Projesi. İstanbul.

Şahin, S., Öztürk, B. ve Ardalı Büyükarman, D. (2013). Edebiyatın İzinde Polisiye Edebiyat. İstanbul: Bağlam Yayıncılık.

Şemseddin Sami. (2009). Kamus-ı Türkî. İstanbul: Kapı Yayınları.

Tahir Gürçağlar, Ş. (2002). What Texts Don’t Tell: The Uses of Paratext in Translation Research. (Ed.) T. Hermans. Crosscultural Transgressions: Research Models in Translation Studies II: Historical and Ideological Issues. Manchester: St. Jerome. 44-60.

Tarakçı, G. (2010). İki Roman Örneğinde Millî Roman. Hece. Türk Romanı Özel Sayısı, 65-67, MayısTemmuz. Ankara. 497-509.

Tekin, M. (2011). Tercüman-ı Hakikat. Türkiye Diyanet Vakfi İslâm Ansiklopedisi. Cilt 40, 497-498. Ankara: TDV Yayınları.

Türkeli, Y. (2005). Tanzimat'tan Sonra Türkçede Roman Tercümeleri (1860-1928). (Yayımlanmamış Yüksek Lisans Tezi). Fatih Üniversitesi, Sosyal Bilimler Enstitüsü, İstanbul.

Üyepazarcı, E. (1997). Korkmayını Mr. Sherlock Holmes. Türkiye'de Yayınlanmış Çeviri ve Telif Polisiye Romanlar Üzerine Bir İnceleme (1881-1928). İstanbul: Göçebe Yayınları. 
680 / RumeliDE Journal of Language and Literature Studies 2020.S7 (October)

A descriptive study on the Ottoman Turkish (re)translations of Arsène Lupin, Gentleman Cambrioleur / G. Güler; A. B. Karadağ (pp. 654-682)

Üyepazarcı, E. (2008). Korkmayını Mister Sherlock Holmes!. Türkiye'de Polisiye Romanın 125 Yıllık Öyküsü. Cilt 1-2. İstanbul: Oğlak Yayınları.

Venuti, L. (2004). Retranslations: The Creation of Value. Translation and Culture. (Ed.) K. M. Faull. Lewisburg: Bucknell University Press. 25-39.

Yalçın, M. (2001). Tanzimat’tan Bugüne Edebiyatçllar Ansiklopedisi. Cilt 1. İstanbul: Yapı Kredi Kültür Sanat Yayıncılık. 


\section{Ekler}

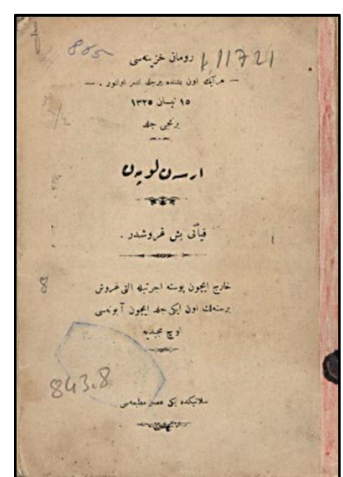

Ek-1

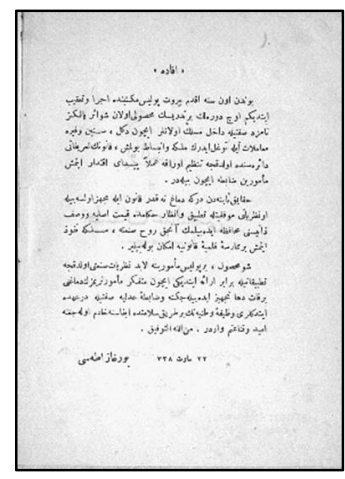

Ek-5

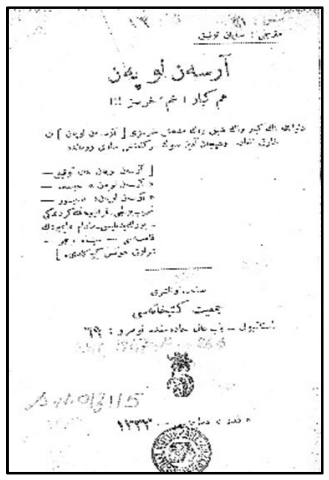

Ek-9

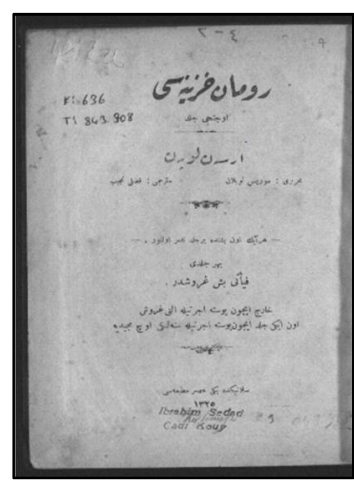

Ek-2

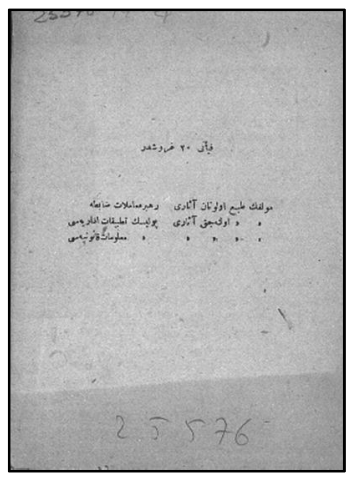

Ek-6

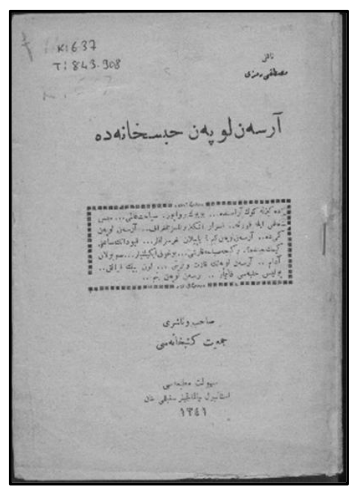

Ek-10

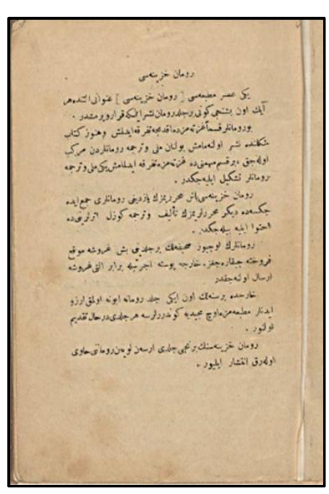

Ek-3

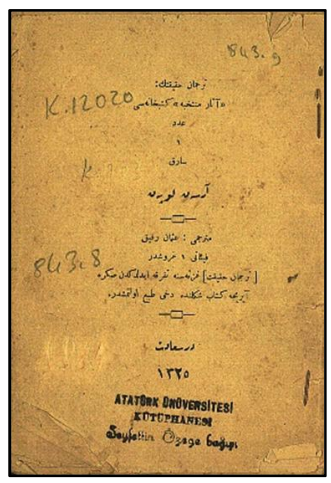

$\mathrm{Ek}-7$

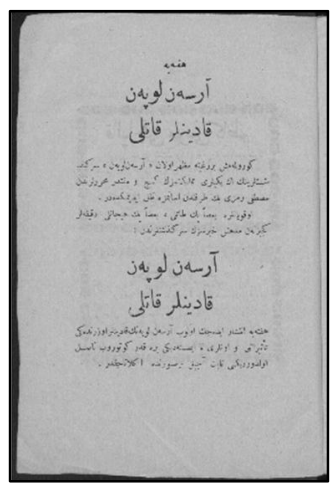

Ek-11

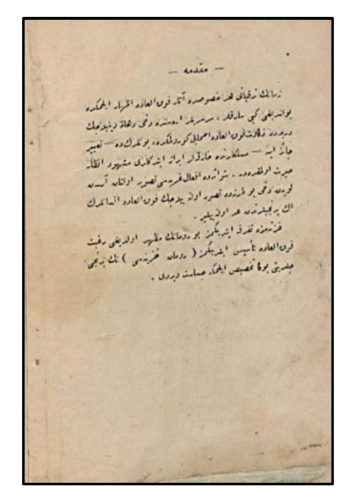

Ek-4

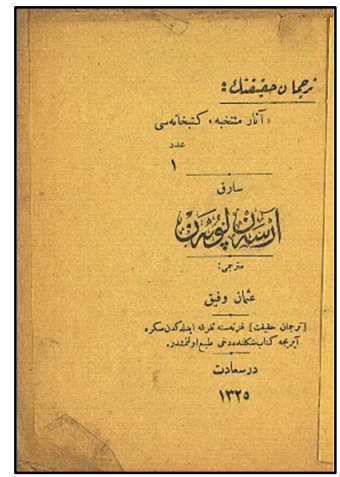

Ek-8

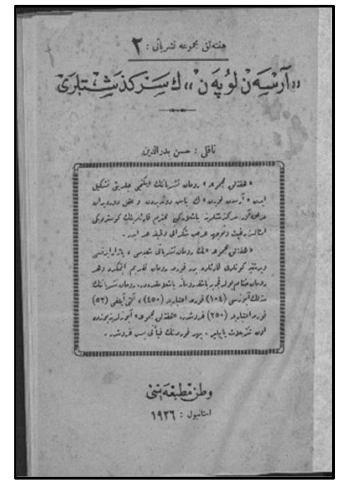

Ek-12 
682 / RumeliDE Journal of Language and Literature Studies 2020.S7 (October)

A descriptive study on the Ottoman Turkish (re)translations of Arsène Lupin, Gentleman Cambrioleur / G. Güler; A. B. Karadağ (pp. 654-682)

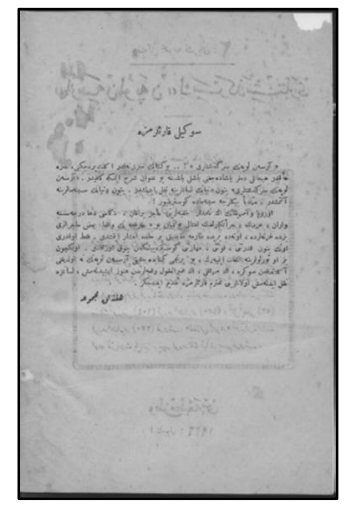

$\mathrm{Ek}-13$

Adres $\mid$ Address

Kırklareli Üniversitesi, Fen Edebiyat Fakültesi, Türk Dili ve Edebiyatı Kırklareli University, Faculty of Arts and Sciences, Department of Bölümü, Kayalı Kampüsü-Kırklareli/TÜRKIYYE Turkish Language and Literature, Kayalı Campus-Kırklareli/TURKEY

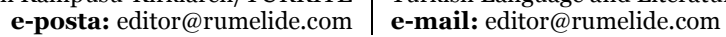

